\title{
Circulating biomarkers in osteosarcoma: new translational tools for diagnosis and treatment
}

\author{
Lavinia Raimondi ${ }^{1,2}$, Angela De Luca ${ }^{1,2}$, Viviana Costa ${ }^{1,2}$, Nicola Amodio ${ }^{3}$, Valeria \\ Carina $^{1,2}$, Daniele Bellavia ${ }^{1,2}$, Pierfrancesco Tassone ${ }^{3}$, Stefania Pagani ${ }^{5}$, Milena Fini ${ }^{5}$, \\ Riccardo Alessandro ${ }^{4,6}$ and Gianluca Giavaresi ${ }^{2,5}$ \\ ${ }^{1}$ Rizzoli Orthopedic Institute, Bologna, Italy \\ ${ }^{2}$ Rizzoli Orthopedic Institute, Innovative Technology Platforms for Tissue Engineering, Theranostic and Oncology, Palermo, Italy \\ ${ }^{3}$ Department of Experimental and Clinical Medicine, Magna Graecia University of Catanzaro, Catanzaro, Italy \\ ${ }^{4}$ Biology and Genetics Unit, Department of Biopathology and Medical Biotechnology, University of Palermo, Palermo, Italy \\ ${ }^{5}$ Rizzoli Orthopedic Institute, Laboratory of Preclinical and Surgical Studies, Bologna, Italy \\ ${ }^{6}$ Institute of Biomedicine and Molecular Immunology (IBIM), National Research Council, Palermo, Italy
}

Correspondence to: Lavinia Raimondi, email: lavinia.raimondi@ior.it

Keywords: biomarkers, osteosarcoma, personalized medicine, liquid biopsy, blood serum

Received: May 10, $2017 \quad$ Accepted: July 25, $2017 \quad$ Published: August 03, 2017

Copyright: Raimondi et al. This is an open-access article distributed under the terms of the Creative Commons Attribution License 3.0 (CC BY 3.0), which permits unrestricted use, distribution, and reproduction in any medium, provided the original author and source are credited.

\section{ABSTRACT}

Osteosarcoma (OS) is a rare primary malignant bone tumour arising from primitive bone-forming mesenchymal cells, with high incidence in children and young adults, accounting for approximately $60 \%$ of all malignant bone tumours. Currently, long-term disease-free survival can be achieved by surgical treatment plus chemotherapy in approximately $60 \%$ of patients with localized extremity disease, and in $\mathbf{2 0 - 3 0 \%}$ of patients with metastatic lung or bone disease. Diagnosis of primary lesions and recurrences is achieved by using radiological investigations and standard tissue biopsy, the latter being costly, painful and hardly repeatable for patients. Therefore, despite some recent advances, novel biomarkers for OS diagnosis, prediction of response to therapy, disease progression and chemoresistance, are urgently needed. Biological fluids such as blood represent a rich source of noninvasive cancer biomarkers, which allow to understand what is really happening inside the tumour, either at diagnosis or during disease progression. In this regard, liquid biopsy potentially represents an alternative and non-invasive method to detect tumour onset, progression and response to therapy. In this review, we will summarize the state of the art in this novel area, illustrating recent studies on OS. Although the data reported in literature seem preliminary, liquid biopsy represents a promising tool with the potential to be rapidly translated in the clinical practice.

\section{INTRODUCTION}

Osteosarcoma (OS) is the most common primary bone cancer, histologically characterized by the production of osteoid by malignant cells; its incidence has a bimodal age distribution, with an initial peak at 12-14 years of age and a second after 60 th $[1,2]$. OS is a relatively rare malignancy representing approximately $1 \%$ of all newly diagnosed cancers in adults, and $3-5 \%$ in children [3, 4]. In non metastatic OS, the five years survival rate of patients is between $40 \%$ and $75 \%$, due to the introduction of comprehensive treatment including two to three rounds of chemotherapy, followed by definitive resection, and additional adjuvant chemotherapy. Unfortunately, about $20 \%$ of patients exhibiting metastases at diagnosis, primarily in the lungs, have a poorer prognosis. Notably, a major issue in the treatment of OS patients is represented by chemotherapy resistance, which can also favour the rapid growth of metastatic lesions $[5,6]$.

Due to its high chromosomal instability, OS is characterized by extremely complex karyotypes, including various copy number gains and losses $[7,8]$. 
Several studies highlighted genomic alterations in OS cells and suggested potential candidate genes driving OS pathogenesis, although the precise relationship between genetic instability and the development of OS is still under debate [9]. Gains or losses of entire chromosomes or chromosomal segments have been observed in different regions, containing oncogenes, like MYC and COSP3 $[8,10]$, and tumour suppressor genes, like LSAMP, CDKN2A, RB1, and TP53 [11-13].

Gene mutations, certain bone diseases, inherited cancer syndromes and ionizing radiation represent wellknown risk factors for OS development (Table 1); on the other hand, trauma does not seem a major determinant of OS development, but rather a manifestation of the disease when the tumour weakens a bone so much that it breaks (pathological fracture) [14]. In turn, genetic and environmental factors activate a plethora of cancer-related molecular pathways, whose role in OS pathogenesis is nowadays a matter of intense investigation [15-17].

The diagnosis of OS includes a set of clinical analyses, radiological investigations and the evaluation of the pathological tissue by performing biopsy. Radiography is routinely used as first line imaging modality for evaluating primary bone tumours. Once suspected diagnosis of OS, magnetic resonance imaging (MRI) is performed in order to understand the distribution of the tumour within the bone, to evaluate the presence of soft tissue masses and to detect skip metastases. Even if computed tomography (CT) scanning is less sensitive than MRI in local evaluation of the tumour, it is recommended to detect lung metastases. Likewise, bone scintigraphy permits to detect osseous metastasis in OS, while the role of positron emission tomography (PET) and integrated PET/CT imaging is increasingly considered by clinicians, particularly for monitoring the effect of chemotherapy or to predict progression-free survival [18-23].

To integrate the diagnostic imaging results, histologic analysis performed on biopsy material provides the definitive diagnosis, giving information on the grade of the tumour (Table 2). Bone biopsy can be performed by a core needle method, under the supervision of an interventional radiologist, guided by radiologic imaging [24]. When the site for bone biopsy is not easily accessible, it is associated with surgery, where the orthopedic surgeon removes the entire tumour by performing an open biopsy with a surgical incision. In localized OS, with the advent of chemotherapy, the complete removal or amputation of the affected limb is reduced to approximately $20 \%$ of patients. For metastatic and recurrent OS, following surgical removal of the primary tumour, all operable metastases, most of which in the lungs, need to be removed to significantly improve prognosis. Furthermore, to counteract the possible presence of occult micro-metastasis at diagnosis, routine use of systemic adjuvant chemotherapy increases and improves patient survival $[25,26]$. Most of OS patients are treated with chemotherapy before surgery (neoadjuvant chemotherapy), followed by adjuvant chemotherapy, which usually comprises high dose of methotrexate with leucovorin rescue (also known as Folinic Acid, a medication used to decrease the toxic effects of Methotrexate), Doxorubicin, Cisplatin, with or without Ifosfamide. Usually, 2 or more chemotherapeutic agents can be given together, even if the adverse effects reported in multi-agent chemotherapy treatments may result in toxicity $[6,27]$.

Finally, recent advances in cancer immunology led to reconsider immunotherapy in OS, as recent research has shown that treatments with monoclonal antibodies designed to inhibit immune checkpoint mechanisms (Ipilimumab and Nivolumab) can have therapeutic benefit in patients with OS and lung metastases. Moreover, cytokine therapies seem to be crucial in orchestrating the immune response in OS; for example, administration of IL-2 was able to induce immune activation, probably via NK cells activation, improving prognosis of OS patients [28-31]. The usefulness of laboratory markers, generally represented by alkaline phosphatase (ALP) and lactate dehydrogenase (LDH), is still considered controversial, although high LDH levels are detected in about $40 \%$ of OS cases and correlate with adverse prognosis. Several studies investigated serum levels of ALP and LDH, indicating that serum concentrations are not always predictive of response to treatment and/or disease progression [32].

Likewise, bone resorption markers, such as $\beta$-isomerized C-terminal telopeptides ( $\beta$-CTx) and total procollagen type 1 amino-terminal propetide (tP1NP), were found at higher levels in serum of OS patients respect to healthy volunteers. However, $\beta$-CTx and tP1NP serum levels were irregular in patients during disease progression, thus not representing valuable candidate biomarkers [33]. Nevertheless, reliable and clinically useful blood markers are currently lacking. On this basis, there is an urgent need for identifying novel and effective biomarkers for OS diagnosis and outcome prediction.

Currently, the analysis of bioptic tissues from primary lesions remains the gold standard to gain essential information on diagnosis, prognosis, prediction of response or resistance to treatment. Tissue biopsy usually provides detailed information on cancer tissue architecture, allowing molecular and histological analysis; unfortunately, such approach has several limitations being an invasive and costly technique, which relies upon few cells or tissue sections that do not necessarily recapitulate the heterogeneity of the whole tumour. Furthermore, multiple biopsies are not feasible for many types of patients, such as the elderly or those with comorbid conditions. In contrast to conventional biopsy, liquid biopsy of tumour components in blood represents a simple and rapid test, easily performed and requiring small amount of sample (usually 10-15 ml of blood), potentially 
opening new possibilities for cancer characterization and management. It represents a rich source of non invasive biomarkers, useful from early cancer detection to therapy selection and cancer patient monitoring during the course of disease (Figure 1).

An overview of the recent information about candidate circulating biomarkers in OS is reported below.

\section{LIQUID BIOPSY}

Liquid biopsy can be performed to detect circulating tumour microRNAs (miRNAs) and long non-coding RNAs (lncRNAs), circulating tumour cells (CTCs), circulating tumour DNA (ctDNA), and microvesicles/ exosomes released into the blood from malignant cells. Such novel approach does not require surgical biopsy, but still provides clinicians with a wide range of information, including tumour origin, staging, patients' response to therapy and emergence of drug resistance. By performing repeated sampling, liquid biopsy may be useful for early tumour assessment and may improve the identification of micro-metastasis and minimal residual disease, only partially detectable by conventional diagnostic methods. Notably, it may reflect the entire heterogeneity of the disease, useful for better monitoring the molecular changes within the tumour in real time [34].

Liquid biopsy offers remarkable advantages over traditional tissue biopsy, however researchers need to elaborate accurate and reproducible blood tests for routine clinical practice (Table 3). In particular, variables in preanalytical (collection, preservation and storage of biosamples), analytical (quantification and analysis of biosamples) and post-analytical (data collection and interpretation) phases should be considered and validated in depth. Furthermore, liquid biopsy test needs to be more:
1) sensitive, capable to detect precisely small amounts of circulating tumour components, and 2) specific, capable to correctly identify and discriminate among tumour circulating components and non-tumour derived components [35].

Complex data obtained by liquid biopsy should be then integrated in a dedicated database with information derived from tissue biopsy, and ultimately integrated by both pathologists and oncologists to design personalized cancer treatments.

\section{SERUM MICRORNAS}

MiRNAs are short non-coding RNA molecules (2225 nucleotides in length) able to regulate gene expression, affecting the stability and/or translation of target mRNAs $[36,37]$. miRNA biogenesis occurs into the nucleus, where an initial transcript, termed pri-miRNA, is transcribed by a RNA polymerase II; pri-miRNA contains an imperfectly double-stranded region within a hairpin loop and is subsequently cleaved by Drosha nuclease, into a 70100 bp pre-miRNA. Pre-miRNA is bound by exportin-5 in a complex with Ran and GTP and translocates through the nuclear pore into the cytoplasm, wherein it is cleaved by Dicer in an imperfect double-stranded miRNA of about 20-22 bp. Thereafter, the miRNA duplex is unwound and the mature miRNA strand binds to an Argonaute protein (AGO1-4) into a ribonucleoprotein (RNP) complex, commonly known as RISC, which drives the mature miRNA strand to the 3'-UTR mRNA target sequence. Depending on the degree of complementarity between the miRNA and its target mRNA, miRNA binding to 3'UTR represses translation or induces deadenylation and mRNA decay [38-40]. By regulating the expression of target genes, miRNAs control many biological processes such as cell proliferation, differentiation and apoptosis. An
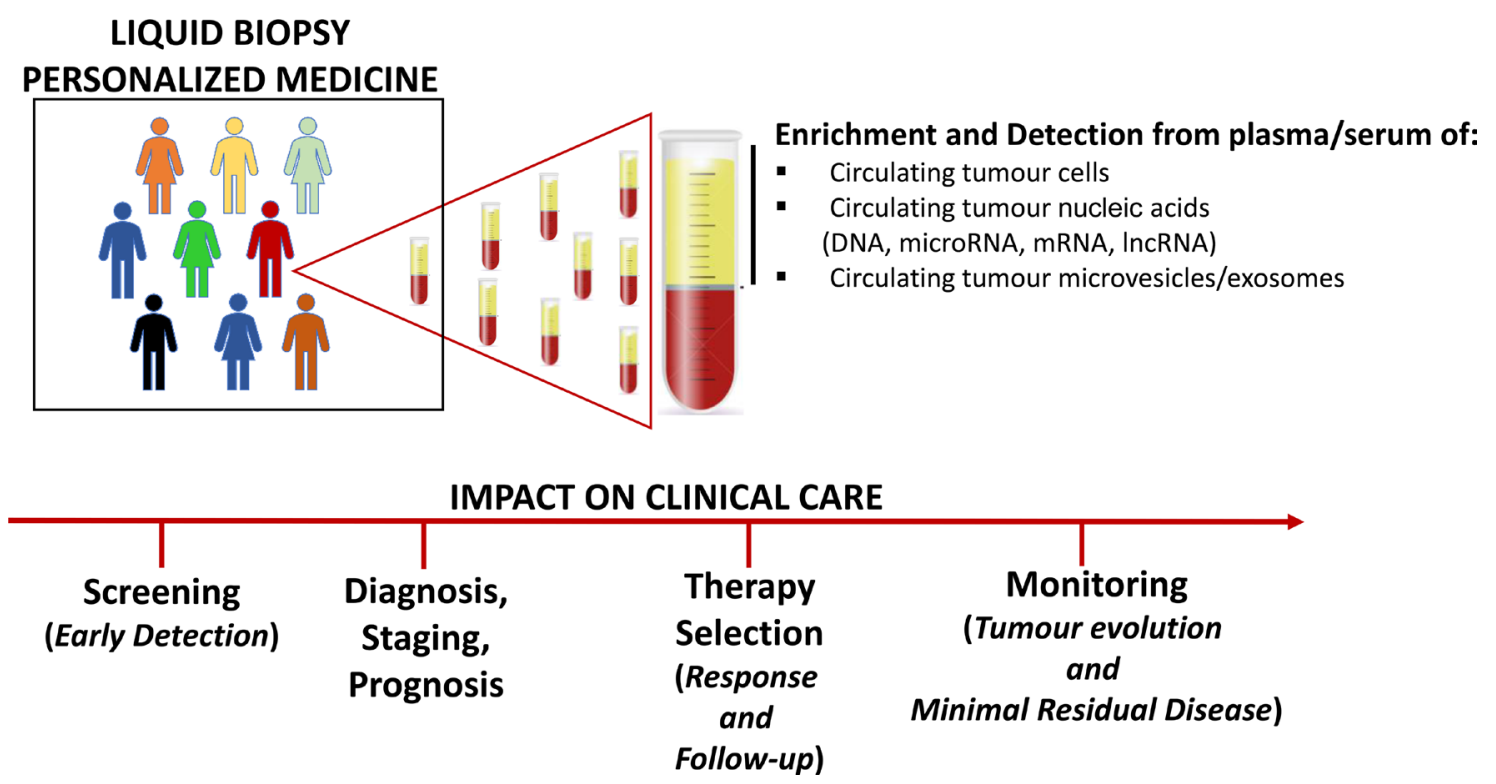

Figure 1: Clinical application of liquid biopsy into the management of cancer. 
Table 1: Risk factors in OS development

\begin{tabular}{|l|l|}
\hline $\begin{array}{l}\text { AGE: OS is more frequent between the ages of } 10 \text { and 30, especially during the teenage growth spurt. A } \\
\text { link between rapid bone growth and risk of tumour formation has been described. }\end{array}$ & $\begin{array}{l}\text { Refence: } \\
{[2]}\end{array}$ \\
\hline GENDER: OS is more common in males than in females & {$[2]$} \\
\hline $\begin{array}{l}\text { INHERITED GENETIC CONDITIONS: } \\
\text { Autosomal dominant disorder Li-Fraumeni, characterized by the germline mutation of the gene p53. }\end{array}$ \\
$\begin{array}{l}\text { Inherited form of retinoblastoma, characterized by the germline mutation in RB1 gene. } \\
\text { Inherited autosomal recessive disorder Rothmund-Thomson syndrome, characterized by a mutation } \\
\text { in the RECQL4 helicase gene. }\end{array}$ \\
$\begin{array}{l}\text { Inherited autosomal recessive disorder Bloom syndrome. } \\
\text { Rare disorder Diamond-Blackfan anaemia characterized by congenital deficiency of red blood cell } \\
\text { precursors resulting in pure red cell aplasia. }\end{array}$ \\
\hline $\begin{array}{l}\text { PAGET DISEASE: focal disorder of bone metabolism characterized by abnormal osteoclast resorption } \\
\text { activity associated with inadequate remodelling mechanisms. }\end{array}$ \\
\hline $\begin{array}{l}\text { RADIATION THERAPY: Exposure to ionizing radiation, either inadvertently or high doses of } \\
\text { therapeutic radiation, induces DNA damage by conferring distinctive mutational signatures. }\end{array}$ \\
\hline $\begin{array}{l}\text { ALKYLATING AGENTS: Exposure to alkylating antineoplastic agents, usually used as } \\
\text { chemotherapeutics, increases the risk of develop secondary OS, especially in primary Ewing sarcoma } \\
\text { patients receiving chemotherapy associated with high doses of radiotherapy. }\end{array}$ \\
\hline
\end{tabular}

Table 2: Two staging system employed for OS

\begin{tabular}{|l|}
\hline Enneking MSTS staging system \\
\hline Stage I Low-grade, no metastasis \\
IA: intra compartmental \\
IB: extra compartmental \\
Stage II High-grade, no metastasis \\
IIA: intra compartmental \\
IIB: extra compartmental \\
Stage III Low or High-grade, presence of metastasis \\
AJCC staging system \\
Stage I Low-grade, no metastasis \\
IA: size $<8 \mathrm{~cm}$ \\
IB: size $>8 \mathrm{~cm}$ \\
Stage II High-grade, no metastasis \\
IIA: size $<8 \mathrm{~cm}$ \\
IIB: size $>8 \mathrm{~cm}$ \\
Stage III Skip metastasis (any grade, any size) \\
Stage IVA Pulmonary metastasis (any grade, any size) \\
Stage IVB Non Pulmonary metastasis (any grade, any size)
\end{tabular}

1. Staging system of the Musculoskeletal Tumour Society (MSTS) [170]. 2. Staging system for bone sarcoma of the American Joint Committee on Cancer System (AJCC).

increasing body of data showed how aberrantly expressed miRNAs contribute to the pathogenesis of several types of tumours, acting as oncogenes or tumour suppressors [41].

Several research groups investigated circulating miRNAs for their diagnostic and prognostic potential, suggesting them as excellent blood cancer biomarkers [42]. Unlike intracellular RNA, circulating miRNAs are particularly stable as they are packaged in exosomes or associated with RNA binding proteins. Moreover, miRNAs can be found in body fluids loaded into high- density lipoprotein (HDL), or bound by AGO2 protein outside the vesicles; all of these associations prevent miRNA from being processed by ribonucleases. MiRNAs are also resistant to boiling, $\mathrm{pH}$ changes and repeated freeze-thawing cycles which make them very easy to handle. However, although circulating miRNAs are remarkably stable in serum, appropriate and reliable methodologies are recommended during collection and analysis of circulating miRNAs, in order to avoid variability in miRNA assessment $[43,44]$. 


\section{LIQUID BIOPSIES}

(circulating tumour cells, circulating nucleic acids, exosomes)

\section{ADVANTAGES}

- Isolation from many biological fluids and sources of non-invasive biomarkers

- Less expensive, quick and easily repeatable tests

- Minimal Pain/Risk

- Non-invasive techniques for early cancer diagnosis and monitoring of disease progression (real-time monitoring of patients)

- Assessment of tumour heterogeneity and dynamics

- Possibility to perform continuous follow-up examinations CLINICAL APPLICATIONS

LIMITATIONS

- Screening for cancers in high-risk populations

- Early diagnosis of cancer and monitoring early therapeutic response

- Assessment of tumour heterogeneity to guide personalized treatment decisions

- Prediction of metastasis and drug resistance

- Detection of minimal residual disease after surgery/recurrence

- Detection of new cancer driver mutations
- Molecular protocols need to be standardized: still too few laboratory applications

- Management of small amounts and easily degradable materials after harvesting, thus requiring extremely sensitive and specific analytic methods

- Poor information on adequate controls

- False-positive and false-negative results: risk of not correctly evaluating the efficacy of a pharmacological treatment.

- Microenvironmental changes may influence the release or the amount of biological materials
Several in vitro and in vivo studies have investigated the role of miRNAs also in OS, underlying their involvement in the onset, progression, and response to chemotherapeutic agents. MiRNAs have gained increasing attention in the management of OS also for their potential applications in diagnosis, prognosis and treatment of this malignancy [44]. Notably, the development of a sarcoma miRNA expression database (S-MED), including OS, identified miRNAs specifically overexpressed or downregulated in specific sarcoma types. MiRNA expression signatures might provide valuable information on sarcoma biology, development of miRNA-based biomarkers, and may improve treatment planning [45]. In particular, several clinical studies investigated the clinicopathological, diagnostic and prognostic value of circulating miRNAs in OS patients' serum; the results obtained underscored the potential of circulating miRNAs as useful noninvasive biomarkers for early detection and monitoring of OS (Tables 4 and 5, Supplementary Table 1).

In the vast majority of published studies, the main methods used for detecting circulating miRNAs are represented by quantitative real time-PCR (qRT-PCR), gene arrays and sequencing [46].

\section{Tumour suppressor miRNAs}

Table 4 reports the clinical significance of tumour suppressor miRNAs in OS. Deregulation of miR-326 was associated with several physiological and pathological processes; in cancer, miR-326 was associated with bone metastatic progression and chemotherapy resistance by modulating the expression of multidrug resistanceassociated protein 1 MRP1 [47, 48]. MiR-326 resulted down-regulated in both OS patients' serum and tissues, compared with healthy controls and adiacent normal tissues. In particular, miR-326 expression status in serum could strongly discriminate OS from healthy volunteers. The patients with a lower expression of miR-326 tended to have distant metastasis and advanced tumour stage, as well as a shorter overall survival compared to patients with high miR-326 serum expression. In view of these results, the authors indicated that miR-326 might represent an independent prognostic biomarker for overall survival in OS, particularly for patients with advanced disease. Furthermore, by in vitro assays, the authors investigated the role of miR-326 in OS invasion and apoptosis, which was dependent on the targeting of the tumour apoptosis inhibiting Bcl-2 gene [49].

MiR-133b and miR-206, two muscle-specific miRNAs, were found to be down-regulated in OS cell lines, where they negatively interfered with cell proliferation and invasion, while promoting apoptosis; conversely, miRNA overexpression reverted these phenotypes [50, 51]. Serum and tissue levels of both miR-133b and miR-206 in OS patients were positively correlated and markedly lower than those, respectively, in healthy volunteers and non cancerous bone tissues. Thereafter, the potential prognostic value of the circulating miRNAs was evaluated in serum: low expression levels of both miR-133b and miR-206 were closely related to a shorter overall and disease-free survival; conversely, patients with high miR-133b/miR-206 ratio had a better prognosis. Low miR-133b and low miR-133b/miR-206 
Table 4: Clinical significance of circulating tumour suppressor miRNA(s) in OS

\begin{tabular}{|c|c|c|c|c|}
\hline $\begin{array}{l}\text { Tumour suppressor } \\
\text { miRNA(s) }\end{array}$ & Patient cohort & Sample & Clinical observation & Study \\
\hline $\operatorname{miR}-326$ & $\begin{array}{l}60 \text { OS pts; } \\
20 \mathrm{HCs}\end{array}$ & $\begin{array}{l}\text { Serum } \\
(60 \text { OS \& } 20 \mathrm{HC}) \\
\text { Tissues } \\
(30 \text { tumour tissue \& } \\
30 \text { adjacent normal tissue) }\end{array}$ & $\begin{array}{l}\text { Lower serum miR-326 levels were found in OS pts compared to } \mathrm{HC}(0.43 \text {-fold decrease, } p<0.05) \text {. } \\
\text { Lower tissue miR-326 levels were found in tumour tissue in comparison to adjacent normal one }(\approx 0.44 \text {-fold } \\
\text { decrease, } p<0.05) \text {. } \\
\text { Low serum miR-326 levels were associated in OS pts with advanced clinical stage }(p<0.05) \text { and distant } \\
\text { metastasis }(p<0.05) \text {, while low tissue miR-326 levels with distant metastasis }(\mathrm{p}<0.05) \text {. } \\
\text { MiR-326 differentiated OS from HC: AUC }=0.897 \text {, cut-off value }=1.76 \text {, sensitivity }=0.84 \text {; specificity }=0.95 \text {. } \\
\text { Serum miR-326 expression was found to be an independent prognostic factor of unfavorable survival (Cox } \\
\text { regression) in OS pts for S: HR }=3.90 \text { [ } 95 \% \mathrm{CI}=1.13-12.35], p=0.001 \text {. }\end{array}$ & [49] \\
\hline $\begin{array}{l}\text { miR-133b } \\
\text { miR-206 }\end{array}$ & $\begin{array}{l}100 \mathrm{OS} \mathrm{pts} \\
100 \mathrm{HC}\end{array}$ & $\begin{array}{l}\text { Serum } \\
(100 \text { OS \& } 100 \mathrm{HC}) \\
\text { Tissues } \\
(100 \text { tumour tissue \& } \\
100 \text { adjacent normal tissue })\end{array}$ & $\begin{array}{l}\text { Lower serum miR-133b and miR-206 levels were found in OS pts compared to HC (miR-133b: } \approx 0.42 \text {-fold } \\
\text { decrease, } p<0.001 \text {; and miR-206: } \approx 0.50 \text {-fold decrease, } p<0.001 \text {. } \\
\text { Lower tissue: miR-133b and miR-206 levels were found in tumour tissue in comparison to adjacent normal } \\
\text { one (miR-133b: } \approx 0.58 \text {-fold decrease, } p<0.001 \text {; and miR-206: } \approx 0.50 \text {-fold decrease, } p<0.001 \text { ). } \\
\text { MiRNAs levels positively correlated in OS tissues and sera (miR-133b: } r=0.56, p=0.01 ; \text { miR-206: } r= \\
0.69, p=0.001 \text { ). } \\
\text { Downregulation of both miR-133b and miR-206 was associated with high tumor grade }(\mathrm{p}=0.006 \text { ), } \\
\text { metastasis }(p<0.001 \text { ), recurrence }(p<0.001 \text { ), and the poor response to chemotherapy ( } \mathrm{p}=0.01 \text { ). } \\
\text { Both serum miR-133b and miR-206 expressions were found to be independent prognostic factors of } \\
\text { unfavorable survival (Cox regression) in OS pts for: } \\
S \text { (miR-133b: HR 5.36 [95\% CI }=1.26-11.03], \mathrm{p}=0.02 ; \text { mir-206: HR } 5.42[95 \% \mathrm{CI}=1.31-11.28] \mathrm{p}= \\
\text { 0.02); and miR-133b/miR-206: HR 9.28 [95\% CI }=2.69-20.79] p=0.001 \text { ), and } \\
\text { PFS (miR-133b: HR 5.69 [95\% CI }=1.33-11.26], p=0.02 ; \text { miR-206: HR 5.88 [95\% CI }=1.56-12.08] \text {, } \\
p=0.02 \text {; and miR-133b/miR-206: HR 9.69 [95\% CI }=2.80-21.82], p=0.001) .\end{array}$ & {$[52]$} \\
\hline miR-152 & $\begin{array}{l}80 \mathrm{OS} \text { pts; } \\
20 \mathrm{HC} \\
20 \text { periostitis pts }\end{array}$ & $\begin{array}{l}\text { Serum } \\
(80 \text { OS, } 20 \text { HC \& } 20 \text { periostitis }) \\
\text { Tissues } \\
((80 \text { OS, } 20 \text { HC \& } 20 \text { periostitis })\end{array}$ & $\begin{array}{l}\text { Lower serum miR-152 levels were found in OS pts compared to HC and periostitis pts. }(\approx 0.27 \text {-fold decrease, } \\
p<0.01) \text {. } \\
\text { Lower tissue miR-152 levels were found in tumour tissue in comparison to adjacent normal or periostitis } \\
\text { ones }(\approx 0.20 \text {-fold decrease, } p<0.01) \text {; } \\
\text { MiR-152 expression was associated with Enneking }(p<0.0005) \text { and metastasis }(p<0.0005) \text {. } \\
\text { MiR-152 differentiated OS from HC: AUC }=0.956 \text {, cut-off value }=3.5 \text {, sensitivity }=0.93 \text {; specificity }=0.96 \text {. } \\
\text { Serum miR-152 expression was found to be an independent prognostic factor of unfavorable survival (Cox } \\
\text { regression) in OS pts for S: } \mathrm{HR}=0.13[95 \% \mathrm{CI}=0.02-0.70], p=0.004 \text {. }\end{array}$ & [53] \\
\hline miR-95-3p & $\begin{array}{l}133 \mathrm{OS} \mathrm{pts} \\
133 \mathrm{HC}\end{array}$ & $\begin{array}{l}\text { Serum } \\
(133 \text { OS \& } 133 \mathrm{HC}) \\
\text { Tissues } \\
\text { (133 tumour tissue) }\end{array}$ & $\begin{array}{l}\text { Low serum miR-95-3p were found in OS pts compared to HC }(0.77 \text {-fold decrease, } p<0.0001) \text {. } \\
\text { Low serum miR-95-3p levels were associated with clinical stage }(p<0.0005) \text {, metastasis }(p<0.0005) \text { and } \\
\text { response to chemotherapy }(p<0.0005) \text {. } \\
\text { MiR-95-3p differentiated OS from HC: AUC }=0.863 \text {. } \\
\text { Serum miR-95-3p expression was found to be an independent prognostic factor of unfavorable survival (Cox } \\
\text { regression) in OS pts for S: HR }=4.22[95 \% \mathrm{CI}=2.31-8.07], p=0.014) \text {. }\end{array}$ & [54] \\
\hline $\operatorname{miR}-34 b$ & $\begin{array}{l}133 \text { OS pts; } \\
133 \mathrm{HC}\end{array}$ & $\begin{array}{l}\text { Plasma } \\
(133 \text { OS \& } 133 \mathrm{HC}) \\
\text { Tissues } \\
\text { (133 tumour tissue \& } 133 \text { adjacent } \\
\text { normal tissue })\end{array}$ & $\begin{array}{l}\text { Lower plasma miR-34b levels were found in OS pts compared to } \mathrm{HC}(\approx 0.80 \text {-fold decrease, } p=0.001) \text {. } \\
\text { Lower tissue miR-34b levels were found in tumour tissue in comparison to adjacent normal one }(\approx 0.20 \\
\text { fold decrease, } p<0.0005) \text {. } \\
\text { Plasma miR-34b levels positively correlated in OS tissues }(r=0.21, p=0.004) \text {. } \\
\text { Lower miR-34b levels were found in metastatic pts compared to non-metastatic ones }(p=0.004) \text {. }\end{array}$ & {$[55]$} \\
\hline miR-195 & $\begin{array}{l}166 \mathrm{OS} \mathrm{pts} \\
60 \mathrm{HC}\end{array}$ & $\begin{array}{l}\text { Serum } \\
(166 \text { OS \& } 60 \text { HC) }\end{array}$ & $\begin{array}{l}\text { Lower miR-195 levels were found in OS pts compared to HC }(0.46 \text {-fold decrease, } p<0.001) \text {. } \\
\text { Low miR-195 levels were associated with advanced clinical stage }(p=0.002) \text {, positive distant metastasis } \\
(p=0.008) \text {. } \\
\text { MiR-195 differentiated OS from HC: AUC }=0.892 \text {, cut-off value }=1.96 \text {, sensitivity }=0.88 \text {; specificity } \\
=0.83 \text {. } \\
\text { MiR-195 expression was found to be an independent prognostic factor of unfavorable survival (Cox } \\
\text { regression) in OS pts for S: } \mathrm{HR}=5.16[95 \% \mathrm{CI}=1.92-11.88], p=0.002) \text {, and DFS (HR }=3.62[95 \% \mathrm{CI} \\
=1.82-9.09], p=0.01) \text {. }\end{array}$ & {$[56]$} \\
\hline $\operatorname{miR}-223$ & $\begin{array}{l}112 \mathrm{OS} \mathrm{pts} \\
50 \mathrm{HC}\end{array}$ & $\begin{array}{l}\text { Serum } \\
(112 \text { OS \& } 50 \mathrm{HC})\end{array}$ & $\begin{array}{l}\text { Lower miR-223 levels were found in OS pts compared to HC }(0.31 \text {-fold decrease, } p<0.01) \text {. } \\
\text { Lower miR-223 levels were associated with more advanced clinical stage }(p<0.001) \text { and positive distant } \\
\text { metastasis }(p<0.001) \text {. } \\
\text { MiR- } 223 \text { differentiated OS from HC: AUC }=0.926 \text {, cut-off value }=1.76 \text {, sensitivity }=0.90 \text {; specificity } \\
=0.97 \text {. } \\
\text { MiR-223 expression was found to be an independent prognostic factor of unfavorable survival (Cox } \\
\text { regression) in OS pts for S: }(\mathrm{HR}=4.59,[95 \% \mathrm{CI}=1.84-11.45], p=0.001) \text {. }\end{array}$ & [57] \\
\hline miR-497 & $\begin{array}{l}185 \mathrm{OS} \mathrm{pts} \\
130 \mathrm{HC}\end{array}$ & $\begin{array}{l}\text { Serum } \\
(185 \text { OS \& } 130 \mathrm{HC})\end{array}$ & $\begin{array}{l}\text { Lower miR-497 levels were found in OS pts compared to } \mathrm{HC}(\approx 0.27 \text {-fold decrease, } p<0.001) \text {. } \\
\text { Lower miR-497 levels were associated with clinical stage }(p=0.001) \text {, distant metastasis }(\mathrm{p}=0.001) \text { and } \\
\text { response to chemotherapy }(p=0.007) \text {. } \\
\text { MiR-497 differentiated OS from HC: AUC }=0.848[95 \% \mathrm{CI}=0.773-0.923] \text {, cut-off value }=0.99 \text {. } \\
\text { MiR-497 expression was found to be an independent prognostic factor of unfavorable survival (Cox } \\
\text { regression) in OS pts for S: }(\mathrm{HR}=3.79,[95 \% \mathrm{CI}=1.99-8.57], p=0.004) \text {. }\end{array}$ & {$[58]$} \\
\hline $\operatorname{miR}-497$ & $\begin{array}{l}36 \mathrm{OS} \mathrm{pts} \\
26 \mathrm{HC}\end{array}$ & $\begin{array}{l}\text { Serum } \\
(36 \text { OS \& } 26 \mathrm{HC}) \\
\text { Tissues } \\
(15 \text { stage III tumour tissue \& } 15 \\
\text { adjacent normal tissue })\end{array}$ & $\begin{array}{l}\text { Lower miR- } 497 \text { levels were found in OS pts compared to } \mathrm{HC}(\approx 0.50 \text {-fold decrease, } p<0.01) \text {. } \\
\text { Lower miR-497 levels were found in tumour tissue in comparison to adjacent normal one }(\approx 0.60 \text { fold } \\
\text { decrease } p<0.05) \text {. }\end{array}$ & {$[171]$} \\
\hline $\mathrm{miR}-125 \mathrm{~b}$ & 138 OS pts & $\begin{array}{l}\text { Serum } \\
\text { ( } 82 \text { resectable and } 56 \text { unresectable) }\end{array}$ & $\begin{array}{l}\text { Lower miR-125b levels were found in unresectable OS pts compared to resectable ones }(\approx 0.52 \text {-fold } \\
\text { decrease, } p<0.01) \text {. } \\
\text { Low miR-125b expression was found to be associated with advanced tumour stages }(p=0.006) \text {. } \\
\text { MiR-125b differentiated chemotherapy-resistant OS from chemotherapy-sensitive OS: AUC }=0.793 \text { [ } 95 \% \mathrm{CI} \\
=0.664-0.890] \text {, cut-off value }=0.61 \text {, sensitivity }=0.77 ; \text { specificity }=0.79 \text {. } \\
\text { Low miR-125b levels were associated with shorter OS }(p=0.049) \text { in unserectable pts and shorter DFS }(p \\
<0.001) \text { in resectable ones. }\end{array}$ & {$[61]$} \\
\hline
\end{tabular}

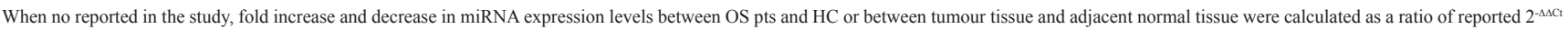
(i.e. serum miR-326 2- $2^{-\Delta C \mathrm{C}}$ in OS / serum miR-326 2-DDCt in HC). Abbreviations: AUC, area under receiving operating characteristics curve; DFS, disease free survival; HC, healthy control/volunteers; HR, hazard ratio; KM, Kaplan-Meier survival curve, L-R, log-rank test; OS, osteosarcoma; PFS, progression free survival; pts, patients; S, overall survival; $95 \%$ CI: $95 \%$ confidence interval. 
Table 5: Clinical significance of circulating lncRNAs in OS

\begin{tabular}{|c|c|c|c|c|}
\hline $\begin{array}{l}\text { Long non coding } \\
\text { RNA(s) }\end{array}$ & Patient cohort & Sample & Clinical observation & Ref. \\
\hline TUG1 & $\begin{array}{l}76 \text { OS pts; } \\
36 \text { pts with benign } \\
\text { bone tumour; } \\
40 \mathrm{HC}\end{array}$ & $\begin{array}{c}\text { Plasma } \\
\text { (29 OS } 1 \text { h before and } 7 \text { days after surgery; } \\
45 \text { OS after systemic treatment; } \\
18 \text { OS experienced disease progression or } \\
\text { relapse; } \\
42 \text { OS newly diagnosed; } \\
36 \text { benign tumour; } \\
40 \mathrm{HC} \text { ) } \\
\text { Tissue } \\
\text { (76 tumour tissue \& } \\
76 \text { adjacent normal tissue) }\end{array}$ & $\begin{array}{l}\text { Higher plasma TUG1 levels were found in OS pts compared to HC } \\
(2.73 \text {-fold increase, } p<0.01) \text {; } \\
\text { Higher tissue TUG1 levels were found in tumour tissue in comparison to } \\
\text { adjacent normal one }(3.46 \text {-fold increase, } p<0.01) \text {. } \\
\text { Higher TUG1 levels in pts with disease progression or relapse compared } \\
\text { with post-treatment pts }(2.71 \text {-fold increase, } p<0.01) \text {. } \\
\text { High expression of TUG1 is an independent prognostic factor of } \\
\text { unfavorable survival (Cox regression) in OS pts with poor S (HR }=2.78 \\
\text { [95\% CI }=1.29-6.00], p=0.009 \text { ) and PFS (HR }=1.81 \text { [ } 95 \% \mathrm{CI}=1.01- \\
3.54], p=0.037) \text {. }\end{array}$ & {$[108]$} \\
\hline $91 \mathrm{H}$ & $\begin{array}{l}67 \text { OS pts; } \\
100 \mathrm{HC}\end{array}$ & $\begin{array}{c}\text { Plasma } \\
(67 \text { OS \& } 100 \mathrm{HC})\end{array}$ & $\begin{array}{l}\text { Higher plasma } 91 \mathrm{H} \text { levels were found in OS pts compared to } \mathrm{HC}(\approx 5.0 \\
\text { fold increase, } p<0.01) \text {. } \\
\text { High plasma } 91 \mathrm{H} \text { levels were associated in OS pts with advanced clinical } \\
\text { stage }(p=0.015) \text {, chemotherapy after surgery }(p=0.023) \text { and tumour } \\
\text { size } \geq 5 \mathrm{~cm}(p<0.001) \text {. } \\
\text { High plasma expression of } 91 \mathrm{H} \text { was found to be an independent } \\
\text { prognostic factor of unfavorable survival (Cox regression) in OS pts with } \\
\text { poor S: higher } 91 \mathrm{H}(\mathrm{HR}=3.14[95 \% \mathrm{CI}=1.32-7.49], p=0.010) .\end{array}$ & [109] \\
\hline UCA1 & $\begin{array}{l}151 \text { OS pts; } \\
74 \mathrm{HC}\end{array}$ & $\begin{array}{c}\text { Serum } \\
\text { (85 OS \&74 HC) } \\
\text { Tissues } \\
\text { (151 tumour tissue \& } \\
151 \text { adjacent normal tissue) }\end{array}$ & $\begin{array}{l}\text { Higher serum UCA1 levels were found in OS pts compared to HC } \\
(\approx 4.80 \text {-fold increase, } p<0.0001) \text {. } \\
\text { Higher tissue UCA1 levels were found in tumour tissue in comparison to } \\
\text { adjacent normal one }(\approx 6.20 \text {-fold increase, } p<0.01) \text {. } \\
\text { High UCA1 levels were associated in OS pts with advanced clinical } \\
\text { stage }(p=0.001) \text { and metastasis }(p=0.007) \text {. } \\
\text { UCA1 differentiated OS from HC: AUC }=0.831[95 \% \mathrm{CI}=0.746- \\
0.916] \text {. } \\
\text { High expression of UCA1 was found to be an independent prognostic } \\
\text { factor of unfavorable survival (Cox regression) in OS with poor S } \\
(\mathrm{HR}=2.52[95 \% \mathrm{CI}=1.35-4.83], p=0.011) \text { and PFS }(\mathrm{HR}=3.14[95 \% \\
\mathrm{CI}=1.66-6.16], p=0.003) \text {. }\end{array}$ & [112] \\
\hline ATB & $\begin{array}{l}60 \text { OS pts; } \\
60 \mathrm{HC}\end{array}$ & $\begin{array}{c}\text { Serum } \\
\text { (60 OS \&60 HC) } \\
\text { Tissues } \\
\text { (60 tumour tissue \& } \\
60 \text { adjacent normal tissue })\end{array}$ & $\begin{array}{l}\text { Higher serum ATB levels were found in OS pts compared to HC }(\approx 10- \\
\text { fold increase, } p<0.0001) \text {. } \\
\text { Higher tissue ATB levels were found in tumour tissue in comparison to } \\
\text { adjacent normal one }(\approx 10 \text {-fold increase, } p<0.0001) \text {. } \\
\text { High ATB levels was associated in OS pts with advanced clinical stage } \\
(p=0.017) \text {, metastasis }(p=0.037) \text {, and recurrence }(p=0.020) \text {. } \\
\text { ATB differentiated OS from HC: AUC }=0.924[95 \% \text { CI }=0.876-0.972], \\
\text { sensitivity }=0.83 \text {; specificity }=0.90 \text {. } \\
\text { High ATB levels were associated (KM compared with L-R) with S } \\
(p=0.0230) \text { and PFS }(p=0.0142) \text {. }\end{array}$ & [113] \\
\hline MALAT-1 & $\begin{array}{l}68 \text { OS pts. } \\
40 \mathrm{HC}\end{array}$ & $\begin{array}{c}\text { Serum } \\
\text { (46 OS \& } 46 \mathrm{HC}) \\
\text { Tissues } \\
\text { (68 tumour tissue \& } \\
68 \text { adjacent normal tissue) }\end{array}$ & $\begin{array}{l}\text { Higher serum MALAT-1 levels were found in OS pts compared to HC } \\
(\approx 1.16 \text {-fold increase, } p<0.001) \text {. } \\
\text { Higher tissue MALAT- } 1 \text { levels were found in tumour tissue in } \\
\text { comparison to adjacent normal one }(\approx 1.32 \text {-fold increase, } p<0.001) \text {. } \\
\text { Higher MALAT- } 1 \text { levels were associated with tumour size }(p=0.008) \\
\text { and distant metastasis }(p<0.0005) \text {. } \\
\text { MALAT1 differentiated OS from HC: AUC }=0.834[95 \% \text { CI }=0.738- \\
0.906] \text {, cut-off value }=3.68 \text {, sensitivity }=0.80 \text {; specificity }=0.73 \text {. } \\
\text { High expression of MALAT1 was associated (KM compared with L-R) } \\
\text { with poor S }(p=0.02) \text { and PFS }(p=0.009) \text {. }\end{array}$ & [116] \\
\hline
\end{tabular}

When no reported in the study, fold increase and decrease in lncRNA expression levels between OS pts and HC or between tumour tissue and adjacent normal tissue were calculated as a ratio of reported $2^{-\Delta \Delta \mathrm{Ct}}$ (i.e. serum $91 \mathrm{H} 2^{-\Delta \Delta \mathrm{Ct}}$ in $\mathrm{OS} /$ serum $91 \mathrm{H} 2^{-\Delta \Delta \mathrm{Ct}}$ in $\mathrm{HC}$ ). Abbreviations: AUC, area under receiving operating characteristics curve; DFS, disease free survival; HC, healthy control/volunteers; HR, hazard ratio; KM, Kaplan-Meier survival curve, L-R, log-rank test; OS, osteosarcoma; PFS, progression free survival; pts, patients; S, overall survival; 95\% CI: 95\% confidence interval.

were also associated with poor response to chemotherapy. Thus, miR-133b, miR-206 independent levels, or in combination, were all independent prognostic factors of a worse survival in OS [52].

Similarly, down-regulation of several serum miRNAs (miR-152, miR-95-3p, miR-34b, miR-195, miR223, miR-497) was associated with OS progression and poor prognosis, suggesting their value as potential serum biomarkers for early detection and clinical evaluation in patients with OS [53-58].

Despite the rapid development and use of multiagent chemotherapy regimens, chemoresistance remains the major cause of treatment failure in the management of OS; thus, an early diagnosis of OS, as well as the 
identification of effective biomarkers predictive of chemoresistance remain crucial for timely and appropriate treatments.

Several studies showed that miRNA deregulation was closely associated with the development of chemoresistance, also in OS [59]. Notably, miR-125b overexpression improved sensitivity of OS cells to cisplatin treatment by targeting the anti-apoptotic protein Bcl-2 [60]. In the study by Luo $\mathrm{Z}$ et al., the correlation between serum miR-125b levels and response to therapy was evaluated in OS patients, which were previously divided in two groups: resectable (received cisplatinbased neoadjuvant and adjuvant chemotherapy and surgery) and unresectable (received cisplatin-based aggressive chemotherapy). In addition, the authors defined chemotherapy sensitivity as complete or in partial remission, while disease progression as sign of chemotherapy resistance. For the resectable group, OS patients with low circulating miR-125b levels experienced shorter disease-free survival, parameter used by the authors to indirectly assess patients' response to chemotherapy. Further, a negative correlation between miR-125b expression and tumour response to cisplatinbased therapy was reported for the unresectable group, where low serum miR-125b levels were associated with advanced tumour stages. Overall, the authors argued that down-regulation of circulating miR-125b might predict poor prognosis and response to cisplatin-based chemotherapy [61].

\section{OncomiRNAs}

Up-regulation of oncogenic miRNAs in OS was associated with the development and progression of this malignancy, suggesting them as attractive potential target for OS therapy. Several studies found a consistent group of circulating miRNAs markedly higher in OS patients than healthy control; moreover, data regarding the association between miRNA levels and clinicopathological features of OS patients showed that the majority of upregulated miRNAs positively correlated with advanced clinical stage, large tumour size, distant metastasis and, in some cases, chemotherapy resistance $[62,63]$. Supplementary Table 1 reports the clinical significance of circulating oncomiRNAs in OS.

Ouyang et al., reported the prognostic utility of the combination of different circulating miRNAs rather than a single miRNA. The expression levels of six candidate miRNAs aberrantly expressed in OS tissues and cell lines, were further evaluated by qRT-PCR in plasma of patients, opening the possibility of using them as noninvasive biomarkers of disease; three miRNAs were considered relevant and validated in 40 OS patients and 40 healthy controls. Consistently, detection of a three-plasma miRNA signature (miR-21, miR-143 and miR-199a-3p) in OS allowed to discriminate diseased from healthy patients with higher accuracy than using individual miRNA. In particular, circulating levels of miR-21 resulted higher in OS patients than controls, while miR-199a-3p and miR143 were decreased. Evaluation of tumour metastatic status and histopatological subtype highlighted higher level of miR-21 in metastatic compared with nonmetastatic patients, while miR-143 had the opposite trend. Similarly, miR-21 levels were significantly increased in osteoblastic compared with non-osteoblastic patients [64].

Likewise, high miR-196a and miR-196b levels, as well as the combined upregulation of circulating miR-196a/miR-196b in OS patients were all considered independent prognostic factor for overall survival and disease free survival. Significant prognostic differences were found among four different groups in relation to miR-196a/miR-196b co-expression, with miR196a-high/ miR196b-high OS patients having the worst prognosis (high tumour grade, presence of metastasis and recurrence of OS patients). Additionally, the levels of those two miRNAs in OS tissues positively correlated with those in patients'sera [65].

TaqMan low-density qPCR (TLDA) technique was used to analyze expression levels of 739 miRNAs in pooled samples from pre- and post-surgery OS patients, and from healthy controls. The results obtained showed that miRNA levels varied between pre-surgery and healthy controls, and also between pre- and post-surgery. Moreover, selected miRNAs were validated by individual qRT-PCR generating a list of 4 miRNAs, including miR195-5p, miR-199a-3p, miR-320a and miR-374a-5p, whose combined co-expression discriminated, with high sensitivity and specificity, OS patients from healthy volunteers. Subsequently, the levels of the 4 miRNAs resulted significantly reduced in the plasma after surgical resection, while, correlation analysis between circulating miRNAs and clinical factors, pointed out that miR-195-5p and miR199a-3p correlated with metastatic status, while miR-320a and miR-374-5p correlated with histological subtype [66].

A similar experimental approach led to identify miR-199a-5p as blood biomarker for pre- and postoperative OS patients. In detail, the authors found significantly high levels of miR-199a-5p in pre-operative OS patients compared with healthy controls; on the other hand, miRNA levels decreased in post-operative compared with pre-operative samples, reaching levels comparable with healthy controls. The proposed study indicates miR$199 a-5 p$ as a powerful biomarker useful for monitoring disease recurrence during post surgery follow-up. Differences in the circulating miRNA levels, secreted by OS cells, strongly correlated with pre and post-operative status, when surgery resection of the tumour seems to induce a drastic reduction of miR-199a-5p released in the bloodstream [67].

Up-regulation of miR-300 was found in OS tissues and cell lines compared with paired adjacent non-cancerous bone tissues and osteoblastic cells. MiR- 
300 is known to promote cell proliferation, invasion and epithelial-mesenchymal transition in OS cell lines [68]; in an attempt to assess the diagnostic value of circulating miR-300, its expression was studied and found strongly up-regulated in OS patients and positively correlated with expression levels of its tissue counterpart. Similarly to miR-199a-5p, serum miR-300 levels decreased in OS patients following curative surgery. High levels of miR-300 were detected in advanced clinical stages and in metastasis, and indicated as an independent predictor factor for poor overall survival and progression freesurvival rate in OS [69]. Of note, the authors underscored an important limitation of using miR-300 as a single biomarker for early detection and monitoring of OS: in fact, circulating miR-300 has been involved in the pathogenesis of other cancers, such as glioma and head and neck squamous cell carcinoma $[70,71]$.

The miRNA-29 family is composed by three members: miR-29a, miR-29b and miR-29c; there is a large body of literature documenting the aberrant expression of these miRNAs in various cancers, with both tumour suppressors and oncogenic roles in a cellular contextdependent fashion [72, 73]. In a physiological setting, miR-29 was found to control osteoblast differentiation by targeting osteonectin, a key factor in bone remodelling; furthermore, miR-29 was reported to play a role in muscle cells development $[74,75]$. In vitro models of multiple myeloma (MM)-related bone disease showed that miR-29b enforced expression counteracted osteoclast differentiation promoted by cancer cells, providing a rationale for a potential novel targeted therapy for MM-related bone disease [76]. Several studies reported deregulation of miR-29 family members in human OS cell lines, although data from different studies are somehow controversial $[77,78]$. In OS patients, high expression levels of miR-29a, miR-29b and miR-29c were detected in tumour tissues and patients'sera, compared with the corresponding adjacent normal tissues or with healthy controls, respectively. In addition, serum and tissue levels of the three miRNAs positively correlated. However, only high miR-29a and miR-29b expression levels correlated with tumour grade, positive metastasis and disease recurrence, as well as with shorter overall and diseasefree survival [79].

Global miRNA expression analysis identified 236 miRNAs as highly expressed in OS patients compared with healthy controls. Among these, eight miRNAs were detected in the culture medium of OS cell lines, meanwhile, qRT-PCR analysis confirmed upregulation of miR-25-3p and miR-17-5p in both OS cells and their derived exosomes. The authors, then, focused on circulating miR-25-3p showing its capability to strongly discriminate OS from non-OS patients (other sarcomas), and from healthy volunteers. Elevated expression of circulating miR-25-3p correlated with clinical distant metastasis and was useful for tumour monitoring during multi-modal treatment, although few cases were analyzed. Likewise, in tumour-bearing mice, miR-25-3p serum levels increased with tumour growth, decreased after tumour resection and, in mice with lung metastasis despite resection, miRNA level increase was revealed again [80].

In OS tissues and cell lines, miR-17 acts as oncomiR by targeting phosphatase and tensine homolog (PTEN), a relevant tumour suppressor gene in cancer. PTEN inactivation or loss of function is found in several tumours, where consequently phosphoinositide 3-kinase (PI3K)/ AKT signaling pathway results activated thus promoting cancer progression. In OS cell lines, silencing of miR-17 leads to increased PTEN expression with decreased cell proliferation, migration and invasion [81]. High PTEN tissue expression frequently occurred in OS patients with a better prognosis, while upregulation of circulating miR-17 was associated with a poor prognosis. Of note, the authors observed a positive correlation among miR-17 serum and tissue levels in OS patients, while circulating miR-17 levels inversely correlated with PTEN tissue expression; notably, the negative correlation between miR-17 and PTEN expression was significantly associated with poor survival in OS patients [82].

Altered levels of miR-221 have been observed in several tumours $[83,84]$; in human OS cell lines, overexpression of miR-221 induced cell survival and cisplatin resistance at least partly through targeting the PI3K/PTEN/ Akt pathway [85]. More interestingly, the diagnostic value of miR-221 was then evaluated in OS patients. The levels of miR-221 were elevated in OS serum and tissue, compared to healthy counterparts; moreover, circulating miR-221 could efficiently discriminate OS patients from healthy volunteers. High circulating miR-221 levels were positively associated with clinical stage and distant metastasis; moreover, miR-221 level was described as an independent prognostic factor for overall survival in OS patients [86].

The onco-miR-27a is abnormally expressed in multiple cancers promoting tumour growth and metastasis [87-89]. Previous studies evaluated the impact of miR27 a overexpression on the metastatic potential of OS cell lines; in detail, enforced expression of miR-27a sustained cancer cell migration and invasion. Furthermore, miR27 acts as an oncogene by targeting the tumour suppressor gene mitogen activated protein kinase 4 (MAP2K4); in turn, MAP2K4 regulates JNK or p38 phosphorylation promoting OS cancer progression [90]. Notably, Tang J et al., observed high miR-27a serum levels in OS patients compared to healthy controls, confirming its strong correlation with aggressive disease (advanced clinical stage and positive distant metastasis) and poor response to chemotherapy. Moreover, circulating miR-27a expression in OS patients was an independent and significant prognostic factor to predict overall survival and diseasefree survival [91].

The identification of novel miRNA-based regulatory pathways involved in apoptosis and chemotherapy 
resistance may provide new promising approaches in OS management. Recently, upregulation of miR-24 levels in OS patients' serum and tissues, when compared with healthy controls and non-cancerous tissues, was shown to be closely related to drug resistance. Based on in vitro studies, such research highlighted novel mechanisms underlying resistance to doxorubicin (DOX), the most common drug used to treat OS. In detail, inhibition of miR24 could overcome chemoresistance, increasing sensitivity of DOX-resistant OS cell lines to chemotherapy. MiR-24 silencing led to upregulation of the pro-apoptotic protein BIM, a member of the Bcl-2 family, and promoted the release of apoptotic factors (such as Smac/DIABLO) from mitochondria, with consequent activation of caspasesdependent cell death. Data obtained showed the miR-24BIM-Smac-DIABLO axis as a novel therapeutic target to enhance OS cell response to DOX, with potentially important consequences on OS management [92].

Despite the crucial role of miRNAs in various biological processes (including proliferation, differentiation, apoptosis) and their documented dysregulation in human cancer, the real clinical uselfulness of miRNAs is under debate.

As previously reported, the recent literature indicates circulating miRNAs as tumour-associated biomarkers useful for early cancer detection, and also for assessing tumour dynamics and drug sensitivities. However, some critical issues in using circulating miRNAs as disease biomarkers need to be considered. In fact, even if miRNAs are considerably stable in clinical plasma samples, it is mandatory to develop standardized protocols for sample collection (from whole blood collection to plasma/serum preparation), miRNA extraction, quantification and data analysis, since pre-analytical and analytical steps can substantially influence miRNA recovery [93].

Additionally, it appears that individual variability, such as race and gender, as well as environmental factors and life-style, such as drug assumption, smoking and nutrition could affect overall circulating miRNA profiles [94-99]. All these variables may finally alter the profile of the single circulating miRNA analyzed, leading to irreproducible results and/or difficult interpretations. Therefore, a more rigorous approach in the study of disease-related biomarkers is recommended, based on extremely sensitive and specific analytic methods as well as on the monitoring of multiple miRNAs in plasma of patients, in combination with common clinicopathological parameters.

\section{SERUM LONG NON-CODING RNAS}

LncRNAs are non-protein coding transcripts longer than 200 nucleotides, implicated in a plethora of biological functions, such as development, differentiation, as well as in regulating gene expression [100]. In cancer, lncRNAs have been widely described for their ability to interfere with oncogenic and tumour-suppressing pathways; among circulating nucleic acids in the blood plasma of cancer patients, the clinical significance of lncRNA levels is increasingly emerging. Notably, several studies detected lncRNAs in body fluids as, for example: PCA3 in prostate cancer, H19 in gastric cancer, HULC in hepatocellular carcinoma, MALAT-1 in non-small cell lung cancer [101104].

Similar to circulating miRNAs, plasmaderived lncRNAs are found in a stable form protected from endogenous RNases or encapsulated within microvesicles, such as exosomes. Nevertheless, accurate techniques to collect, storage and process samples need to be standardized and commonly accepted. In addition, researchers are evaluating the influence of individual and environmental factors on lncRNAs expression levels, in order to establish them as real disease biomarkers. To be sure that changes in expression levels of circulating lncRNA can be used to monitor cancer patient, it will be necessary to develop specific circulating lncRNA signatures unique to individual cancer types compared with healthy subjects [105].

LncRNAs were reported to be involved also in OS pathogenesis, metastasis and chemoresistance. A microarray analysis explored the expression profile of lncRNAs in human primary OS and their noncancerous counterparts; the study highlighted more than 25.000 lncRNAs deregulated, with both oncogenic and tumour suppressive transcripts. Notably, lncRNAs were functional correlated with several signaling pathways implicated in OS proliferation and metastasis [106, 107]. Table 5 reports the clinical significance of circulating lncRNAs in OS.

Taurine up-regulated gene 1 (TUG1) is a potential oncogenic lncRNA that has been shown to support OS cell proliferation and inhibit cell apoptosis. High TUG1 levels were detected in OS tissues when compared with corresponding adjacent normal tissues; in addition, OS patients with high tissue TUG1 levels had a significantly worse prognosis, and TUG1 resulted as an independent prognostic marker for both overall and progression-free survival. The serum levels of TUG1 increased in preoperative patients compared to healthy controls, while it decreased following curative surgery; in particular, its expression levels increased again in patients experiencing disease progression or relapse [108].

Circulating expression profile of $91 \mathrm{H}$, a lncRNA located on the position of the H19/insulin-like growth factor 2(IGF2) locus, was investigated in the serum of OS patients and in healthy controls; interestingly, $91 \mathrm{H}$ overexpression was correlated with advanced clinical stage, chemotherapy after surgery and tumour size (when greater than $5 \mathrm{~cm}$ ). Finally, $91 \mathrm{H}$ overexpression predicted poor overall survival, and was indicated as an independent prognostic factor [109].

LncRNA UCA1 (urothelial carcinoma associated 1) was originally investigated in human bladder cancer; later, 
its deregulated expression was demonstrated in several other tumours [110, 111]. High expression levels of UCA1 were found in OS tissues and patients' sera when compared with controls; in addition, expression of circulating UCA1 significantly correlated with clinical stage and metastasis. Importantly, the authors demonstrated that UCA1 was an independent prognostic factor predicting overall survival and disease free survival in OS patients [112].

LncRNA activated by transforming growth factor- $\beta$ (lncRNA-ATB) has been described in several cancers, including recently OS [113]. Compared with normal controls, the expression levels of circulating lncRNAATB in OS patients resulted significantly increased, and were able to accurately discriminate OS patients from healthy controls. Upregulation of circulating lncRNAATB was found associated with poor prognosis, while its tissue expression correlated with advanced Enneking stage and metastasis. To investigate the biological role of lncRNA-ATB, in vitro assays using ectopically expressed IncRNA-ATB revealed an increase in OS cell proliferation and migration ability; conversely, lncRNA-ATB silencing induced opposite effects. Notably, overexpression of lncRNA-ATB decreased miR-200s while up-regulated its two major targets, zinc finger E-box binding homeobox proteins ZEB1 and ZEB2, finally affecting OS progression [113].

The metastasis associated lung adenocarcinoma transcript 1 (MALAT1), was firstly described as a predictive biomarker for metastasis in the early stage of non-small cell lung cancer and then in other cancers [104]. In OS, MALAT1 promotes proliferation and metastasis of cancer cells by activating the PI3K/Akt pathway [114]; additionally, elevated tissue levels of MALAT1 correlated with advanced clinical stage and distant metastasis, contributing to a shorter survival time [115]. More recently, it was demonstrated that MALAT1 is activated by the transcription factor TGF- $\beta$ and, then, promoted OS metastasis through EZH2-induced suppression of E-cadherin. High MALAT1 serum levels were then associated with tumour size and distant metastasis, but also with poor overall survival and progressive free survival compared with the low expressing patients [116].

\section{SERUM CIRCULATING TUMOUR CELLS}

Development of distant metastases in OS patients originates by spread of cancer cells through the blood vasculature or lymphatic system. Circulating tumour cells (CTCs) are currently considered as a biomarker of disease progression, since they well correlate with the status of metastatic cancer. Appropriate isolation and detection methods allow to monitor the presence and number of CTCs before and after chemotherapy treatment, which likely represent important predictors of prognosis for cancer patients. Furthermore, the analysis of genetic alterations found in CTCs can be used to drive therapeutic decisions. However, CTCs isolation and characterization techniques need to be thoroughly improved in terms of molecular features of the cells, given their fragility, high heterogeneity and the very small amount recovered from the blood [117, 118].

Detection of live CTSc requires highly sensitive and specific methods, usually preceded by an initial step to isolate and enrich tumour cells from blood. Enrichment of CTCs from a large blood volume is a necessary technique, since there is about $1 \mathrm{CTC}$ for $10^{6}$ mononuclear cells. To date there are two main enrichment techniques which include, respectively, physical (including cell size, or electrical charge) and immunomagnetic, antigendependent methods. Filtration methods rely on physical properties that allow the isolation of CTCs by size; in detail, since CTCs are larger in size than hematopoietic cells, only the blood cells pass through the pores (7.5 to $8 \mu \mathrm{m}$ in diameter) of the filters, whereas approximately $85-100 \%$ of CTCs are retained. After isolation, CTCs can be stained (Hematoxylin-eosin or May-Grunwald-Giemsa) and identified using morphologic/cytopathologic criteria. The immunomagnetic antigen-dependent technique selects CTCs by expression of membrane proteins; it is usually performed by positive enrichment of the epithelial cell markers EpCAM and keratins, and also combined with negative depletion of hematopoietic CD45 positive cells $[117,119,120]$.

Due to the mesenchymal origin of OS tumours, selection methods based on expression of epithelialspecific markers are not suitable; therefore, CTCs from OS tumours have been commonly selected by cell size. Screening of cell-surface markers differently expressed on cancer and normal cells provides a convenient method for analyzing CTCs. Vimentin is an intermediate filament highly expressed in mesenchymal cells and correlated with sarcoma migration and invasiveness. Vimentin overexpression was frequently observed in several cancers, and a cell-surface vimentin emerged as an exclusive marker for different subtypes of sarcoma, including OS. The proposed technique exploited a novel monoclonal antibody specifically recognizing a tumoursurface vimentin, thus discriminating cancer cells from mononuclear blood cells that express intracellular vimentin [121, 122].

In a pilot study, investigators evaluated the expression of Collagen I (Col1) by semiquantitative RTPCR in both OS patients and healthy controls, correlating mRNA levels with patients's clinical outcome. Notably, they reported elevated Coll transcript levels in peripheral blood samples from OS patients compared with healthy controls. Furthermore, OS patients characterized at diagnosis by elevated Col1 mRNA levels developed clinical metastases within a year; conversely, no metastases were found in OS patients characterized by low Col1 mRNA transcript levels. Although the number of patients was low, the authors highlighted the potential 
diagnostic and prognostic values of Coll mRNA, being the molecular approach a minimally invasive method to follow up patients after OS diagnosis [123].

A polymerase chain reaction assay based on an enzyme-linked immunosorbent assay (PCRELISA) was developed in order to detect OS CTCs in a mouse metastatic model. The authors used Osf2/ Cbfa1, also called Osf2, as target gene. It is a member of the transcription factors runt involved in osteoblastic differentiation, whose expression is restricted in cells of osteoblastic lineage. In particular, the expression of a splicing variant of $O s f 2$ was limited to normal bone and OS cells, meanwhile Osf2 mRNA was found highly expressed in the blood of metastatic mice compared with the blood of healthy mice [124].

Ezrin, an Ezrin/Radixin/Moesin protein family member, is a linker protein connecting the actin cytoskeleton with plasma membrane. Several studies have demonstrated the involvement of ezrin in sarcoma development and metastasis, describing its association with clinicals parameters of disease progression. Recently, ezrin expression was detected by multiple RNA-in situ hybridization (RNA-ISH) assay in CTCs isolated by peripheral blood of OS patients; of note, the expression of ezrin was higher in stage IIIB than stage IIB (Ennekin staging system: Table1), supporting the hypothesis that ezrin levels positively correlated with distant metastasis [125-128].

More recently, a prospective clinical study described a new method to quantify OS CTCs from blood; this is based on abnormal chromosome numbers (aneuploidy) in CTCs instead of surface markers. Aneuploidy was analyzed by fluorescence in situ hybridization (FISH) using fluorescence-labeled alpha-satellite probes for the centromeres of chromosome (CEP 8). Notably, patients with metastatic OS had more CTCs, and correlative analysis between number of CTCs and progression-free survival revealed a worse prognosis for patients with high CTCs levels [129].

\section{SERUM CIRCULATING TUMOUR DNA}

Cell-free circulating tumour DNA (ctDNA) can be considered as a potential surrogate for the entire tumour genome, as analysis of ctDNA for somatic mutations may be a way to detect and follow the progression of a patient's tumour. The mechanism by which cell-free ctDNA is released into the circulation is still unclear, although these fragments may possibly derive from the primary tumour site, as well as from metastases, or even from apoptotic CTCs $[119,130,131]$. ctDNA released into the blood harbours specific genomic alterations detected in primary tumour; additionally, its somatic genetic alterations reflect the spatial and temporal heterogeneity observed between primary and metastatic tumours, overcoming limitations of single tissue biopsy. Following the recent advances in cancer genome project (CGP) and next generation sequencing (NGS) technology, analysis of genetic lesions by ctDNA might become a reality, despite the small amount of this circulating ctDNA in the blood $[132,133]$. Thus, ctDNA as liquid biopsy may represent an alternative approach for tumour diagnosis, prognosis and personalized therapy, even in OS patients.

In a recent study on primary breast tumours, not all the mutations identified in the metastasis could be detected in the primary lesion; conversely, all mutations identified in plasma-derived DNA were accurately detected (by sequencing analysis of DNA) in tissue biopsies of both primary breast cancer and its synchronous liver metastasis [134]. Importantly, the authors demonstrated that ctDNA analysis is able to capture the heterogeneity of primary tumour and metastasis. One of the most commonly used liquid biopsy analysis is the search of epidermal growth factor receptor (EGFR) mutations, which predicts responsiveness to EGF receptor (EGFR)-tyrosine kinase inhibitors in a distinct clinicopathologic subset of nonsmall-cell lung cancer patients [135].

Due to the rarity of OS disease, the research on ctDNA in OS patients is still preliminary, especially if compared with other tumours. Nevertheless, ctDNA analysis could provide useful information, given the high degree of genetic heterogeneity in OS [136].

A pilot study characterized ctDNA from the plasma of SCID mice injected with OS cells; in particular, DNA extracted was subjected to NGS using custom designed probes for cancer-related genes in OS (TP53, RB1, MET and PTEN). The authors detected over 1000 mutations, already identified as OS-specific mutations, and concluded that the study provided the rationale to use ctDNA within clinical trials [Fremed M, Piperdi S, Zhang W, Maqbool S, Calder B, Castellanos R, et al. Abstract 3133A: Circulating tumour DNA as 'liquid biopsy'in pediatric osteosarcoma. Cancer Research, American Association for Cancer Research-AACR; 2016 Jul 15;76(14 Supplement): 3133A-3133A. Available from: http://dx.doi. org/10.1158/1538-7445.am2016-3133a].

CtDNA may provide information not only for genetic aberrations but also for epigenetic alterations of cell-free DNA. Epigenetic alterations, including changes in DNA methylation and associated histone modifications, are closely related with tumour development and disease progression [137]. CtDNA from cancer patients can account for genetic/epigenetic modifications, because nucleic acid fragments are shed into the circulation from all tumours in a patient's body; notably, differential methylation status of tumour-associated genes matches among ctDNA and corresponding tumour tissues [138]. In OS cell lines, treatment with decitabine, an inhibitor of DNA methylation, led to the upregulation of several genes some of which, like GADD45A, restored apoptotic response [139]. In a recent study, two syngeneic human OS cell lines, derived respectively from a primary 
tumour and a skip metastasis in the same patient, were established. By performing a methylated DNA immunoprecipitation (MeDIP) assay in combination with expression profiling, the authors found a higher increase in Iroquois homeobox 1 (IRX1) expression in highly metastatic OS cells compared with nonmetastatic OS cells. They later confirmed elevated IRX1 expression in metastatic OS patients due to hypomethylation of its own promoter. In OS cell lines, the promoter hypomethylation of the IRXI gene leads to IRX1 overexpression, which in turn exerts its pro-metastatic effects increasing invasion, anoikis resistance in vitro and lung metastasis in vivo. Conversely, in in vitro assays, downregulation of IRX1 in OS cells resulted in decreased CXCL14 expression levels, inhibition of $\mathrm{NF}-\kappa \mathrm{B}$ activity and suppression of metastasis. The analysis of the methylation status of $I R X 1$ promoter in the serum of primary OS patients highlighted that hypomethylated IRXI correlated with worse lung metastasis-free survival, thus suggesting $I R X 1$ hypomethylation as a potential biomarker for early detection of lung metastasis in OS patients [140].

\section{SERUM EXTRACELLULAR VESICLES}

The role of cancer-derived exosomes as novel cellcell signals during tumour growth and progression has been recently highlighted. Exosomes released by cancer cells may affect survival, apoptosis, invasion, angiogenesis and resistance to chemotherapy, and may also prepare the metastatic niche $[141,142]$. These nanovesicles (40-150 $\mathrm{nm}$ ) of endocytic origin actively transport and horizontally transfer information such as proteins, miRNAs and mRNAs to target cells, thus influencing their behaviour and strongly modifying the entire microenvironment. Several reports demonstrated that exosomes enter into a variety of body fluids including blood, where the amount of tumour-derived exosomes is high and increase during tumour progression. Circulating exosomes are emerging as clinically useful tools for cancer detection and high levels of cancer cell derived-exosomes were found in the plasma of patients with breast, colorectal, ovarian and prostate cancers [143-145]. The bioactive molecules carried by exosomes strongly reflect the dynamic changes of the producing cells, particularly during metastatic progression and pharmacological response [146]. Even if standardization procedures in exosomes' isolation and characterization still remain a major challenge, it is well accepted that exosome content is heterogeneous and compatible with the pathological state of their cells of origin, thus making exosome promising biomarkers deserving in-depth investigation.

Therefore, in the last decade researchers have tried to develop circulating exosomesbased biomarkers for use in routine clinical practice. The conventional methods of exosomes isolation allow to analyze nanovesicles but also their molecular content, such as proteins, DNA and miRNAs. To date, the commonly used methods include ultracentrifugation, densitygradient separation, size exclusion chromatography, immunoaffinity capture methods as well as exosomes precipitation and microfluidics-based isolation techniques [147, 148]. Moreover, new alternative approaches, relying on the expression of surface tumour markers, are being developed in order to discriminate tumourderived exosomes from those secreted from healthy cells. Recently, a novel selective capture methodology was reported for exosomes expressing the prostate-specific membrane antigen (PSMA) biomarker, critical for early diagnosis, prognosis and treatment design of prostate cancer [149].

Several studies reported that analysis of tumourspecific antigens by circulating exosomes could improve the sensitivity and specificity to detect and monitor cancer patients. Alegre E et al. detected MIA (Melanoma Inhibitory Activity) and S100B, two markers commonly used to follow patients with advanced melanoma, in circulating exosomes from melanoma patients; their serum quantification could have a diagnostic and prognostic value, as significantly higher levels of both markers have been observed in melanoma patients compared to healthy controls [150]. The membrane-associated protein Glypican-1, described as overexpressed in pancreatic cancer, was found in circulating exosomes of pancreatic cancer patients, distinguishing with good specificity and sensitivity, healthy controls and patients with benign disease from those with early and advanced stages disease. High levels of glypican-1 correlated with metastatic disease burden and the survival of pre- and post-surgical patients [151]. More recently, Liu et al. proposed circulating exosomal miR-23b-3p, miR-10b-5p and miR-21-5p as non-invasive prognostic biomarkers of non-small-cell lung cancer, reporting a poorer overall survival in patients with high expression levels of the three exosomal miRNAs [152].

In OS, similarly to ctDNA, circulating exosomes only now begin to be evaluated within clinical studies enrolling OS patients. Indeed, the specific contents of OSderived exosomes, their contribution to tumorigenesis as well as their role in drug resistance are beginning to be explored by in vitro and in vivo studies. For instance, it has been shown that OS cell lines actively secrete exosomes, which contain many proteins related to biological functions and specifically involved in tumour growth and metastasis. Furthermore, gene ontology analysis of exosomal and non-exosomal fractions revealed also differences in the enrichment of functional categories involved in tumorigenesis [153].

OS-derived extracellular vesicles (OS-EVs) contribute to establish a metastatic niche through induction of IL-6 production by mesenchymal stem cells (MSC), which in turn sustain tumour growth and progression. In an attempt to explore the underlying mechanisms, the 
authors found that an EV-associated form of TGF $\beta$ was responsible of IL-6 production in MSC. In addition, by in vivo studies, "tumour-educated" MSC (TEMSCs) injected in a pre-clinical mouse model supported OS growth and lung metastasis formation, while co-administration of tocilizumab, an interleukin-6 antibody, strongly reduced the effects induced by TEMSCs. Further analysis revealed that serum levels of EV-associated TGF $\beta$ were significantly higher in OS patients compared to healthy controls, supporting a clinical significance [154].

Data obtained in vitro demonstrated that doxorubicin-resistant OS cells may transfer their drugresistance to sensitive cells by releasing exosomes. In particular, exosomes were purified by multidrug resistant human OS MG-63DXR30 (Exo/DXR) and MG63 parental cells $(\mathrm{Exo} / \mathrm{S})$; incubation of OS cells with Exo/DXR decreased the sensitivity of parental cells to doxorubicin, while treatment with Exo/S was irrelevant. Moreover, multidrug-resistance P-glycoprotein mRNA expression increased in MG-63, after incubation with Exo/DXR. Overall, these results indicate that tumourderived exosomes act as vehicles allowing the exchange of biological cargo, specifically contributing to drugresistance mechanisms by transferring the intercellular transfer of MDR-1 mRNA and its product P-glycoprotein [155].

Profiling analysis of exosomal miRNA levels from plasma of OS patients revealed a differential response to chemotherapy, with 12 miRNAs upregulated and 18 miRNAs downregulated in exosomes isolated from patients who had poor response to chemotherapeutic treatment when compared to those with a better status. Validation of differential miRNAs using an independent cohort of 20 OS patients with poor response, 20 OS patients with good response and 20 healthy controls confirmed miR-124, miR-133a, miR-199a-3p and miR385 as significantly reduced in patients who have a poor response to chemotherapy when compared with good responders. Instead, miR-135b, miR-148a, miR-27a and miR-9 resulted highly expressed in circulating exosomes from good responder patients. Data obtained showed that a specific subset of circulating exosomal miRNAs, could be used as reliable diagnostic markers to highly discriminate OS patients with poor chemotherapeutic response from those with good response [156].

\section{CONCLUSIONS}

Osteosarcoma is a rare and highly heterogeneous bone cancer, resulting from the interplay of environment and genes; it occurs most often in young adults and strongly weakens their quality of life. Despite the management of OS has been evolved in the last years, the timely diagnosis and staging of the disease represents a primary prerequisite for successful surgical and pharmacological treatments. Currently, tissue biopsy and imaging are the most common diagnostic tests used by clinicians to detect and monitor treatment for OS; however, obtaining tissue biopsy may be sometimes difficult due to the location or to the small size of the tumour.

The identification of prognostic factors remains a challenge of OS treatment; indeed, the prognostic significance of biomarkers proposed to date is still controversial among the orthopaedic oncologists. In alternative, liquid biopsy represents a non-invasive and time-saving approach that may provide crucial information on early detection, therapeutic decision and response to therapy in OS. Notably, liquid biopsy already represents a reality in clinical practice, as demonstrated by the EGFR genetic testing for non-small cell lung cancer [135].

In spite of several attempts to propose blood-based biomarkers for the clinical management of OS, few biomarkers have already been validated in statistically significant prospective trials. Notably, the studies reported in this manuscript have identified several promising disease biomarkers; data obtained are therefore very encouraging and, if further validated, may provide good candidates usable in non-overlapping biomarker panels for OS. Anyway, the development of such unique and reliable biomarkers must be supported by standardization procedures throughout all phases, from biomarkers discovery to clinical validation. Moreover, it is advisable that the methodologies are validated in multi-center prospective clinical trials with a large cohort of patients. Indeed, a panel of biomarkers should be combined with patients' clinical data to draw a real-life clinical scenario $[157,158]$.

\section{CONFLICTS OF INTEREST}

The authors declare no competing financial interests.

\section{REFERENCES}

1. McKenna RJ, Schwinn CP, Higinbotham NL. Osteogenic sarcoma in children. CA Cancer J Clin. 1966; 16:26-8.

2. Ottaviani G, Jaffe N. The etiology of osteosarcoma. Cancer Treat Res. 2009; 152:15-32.

3. Damron TA, Ward WG, Stewart A. Osteosarcoma, chondrosarcoma, and Ewing's sarcoma: National Cancer Data Base Report. Clin Orthop Relat Res. 2007; 459:40-7.

4. Dorfman HD, Czerniak B. Bone cancers. Cancer. 1995; 75:203-10.

5. He H, Ni J, Huang J. Molecular mechanisms of chemoresistance in osteosarcoma (Review). Oncol Lett. 2014; 7:1352-62.

6. Ferrari S, Smeland S, Mercuri M, Bertoni F, Longhi A, Ruggieri P, Alvegard TA, Picci P, Capanna R, Bernini G, Muller C, Tienghi A, Wiebe $\mathrm{T}$, et al. Neoadjuvant chemotherapy with high-dose Ifosfamide, high-dose methotrexate, cisplatin, and doxorubicin for patients with 
localized osteosarcoma of the extremity: a joint study by the Italian and Scandinavian Sarcoma Groups. J Clin Oncol. 2005; 23:8845-52.

7. Martin JW, Squire JA, Zielenska M. The genetics of osteosarcoma. Sarcoma. 2012; 2012:627254.

8. Bayani J, Zielenska M, Pandita A, Al-Romaih K, Karaskova J, Harrison K, Bridge JA, Sorensen P, Thorner P, Squire JA. Spectral karyotyping identifies recurrent complex rearrangements of chromosomes 8, 17, and 20 in osteosarcomas. Genes Chromosomes Cancer. 2003; 36:7-16.

9. Smida J, Baumhoer D, Rosemann M, Walch A, Bielack S, Poremba C, Remberger K, Korsching E, Scheurlen W, Dierkes C, Burdach S, Jundt G, Atkinson MJ, et al. Genomic alterations and allelic imbalances are strong prognostic predictors in osteosarcoma. Clin Cancer Res. 2010; 16:4256-67.

10. Both J, Wu T, Bras J, Schaap GR, Baas F, Hulsebos TJ. Identification of novel candidate oncogenes in chromosome region 17p11.2-p12 in human osteosarcoma. PLoS One. 2012; 7:e30907.

11. Squire JA, Pei J, Marrano P, Beheshti B, Bayani J, Lim G, Moldovan L, Zielenska M. High-resolution mapping of amplifications and deletions in pediatric osteosarcoma by use of CGH analysis of cDNA microarrays. Genes Chromosomes Cancer. 2003; 38:215-25.

12. Ozaki T, Schaefer KL, Wai D, Buerger H, Flege S, Lindner N, Kevric M, Diallo R, Bankfalvi A, Brinkschmidt C, Juergens H, Winkelmann W, Dockhorn-Dworniczak B, et al. Genetic imbalances revealed by comparative genomic hybridization in osteosarcomas. Int J Cancer. 2002; 102:355-65.

13. Kresse SH, Ohnstad HO, Paulsen EB, Bjerkehagen B, Szuhai K, Serra M, Schaefer KL, Myklebost O, MezaZepeda LA. LSAMP, a novel candidate tumor suppressor gene in human osteosarcomas, identified by array comparative genomic hybridization. Genes Chromosomes Cancer. 2009; 48:679-93.

14. Dorrestijn O, Jutte PC. Osteosarcoma in the distal femur two years after an ipsilateral femoral shaft fracture: a case report. J Med Case Rep. 2011; 5:198.

15. He JP, Hao Y, Wang XL, Yang XJ, Shao JF, Guo FJ, Feng JX. Review of the molecular pathogenesis of osteosarcoma. Asian Pac J Cancer Prev. 2014; 15:5967-76.

16. Ouellet V, Siegel PM. CCN3 modulates bone turnover and is a novel regulator of skeletal metastasis. J Cell Commun Signal. 2012; 6:73-85.

17. Zhou W, Hao M, Du X, Chen K, Wang G, Yang J. Advances in targeted therapy for osteosarcoma. Discov Med. 2014; 17:301-7.

18. Kayton ML, Huvos AG, Casher J, Abramson SJ, Rosen NS, Wexler LH, Meyers P, LaQuaglia MP. Computed tomographic scan of the chest underestimates the number of metastatic lesions in osteosarcoma. J Pediatr Surg. 2006; 41:200-6.
19. Costelloe CM, Macapinlac HA, Madewell JE, Fitzgerald NE, Mawlawi OR, Rohren EM, Raymond AK, Lewis VO, Anderson PM, Bassett RL Jr, Harrell RK, Marom EM. $18 \mathrm{~F}-\mathrm{FDG} \mathrm{PET} / \mathrm{CT}$ as an indicator of progression-free and overall survival in osteosarcoma. J Nucl Med. 2009; 50:340-7.

20. Chaudhry AA, Gul M, Gould E, Teng M, Baker K, Matthews R. Utility of positron emission tomographymagnetic resonance imaging in musculoskeletal imaging. World J Radiol. 2016; 8:268-74.

21. Kaste SC. Imaging pediatric bone sarcomas. Radiol Clin North Am. 2011; 49:749-65, vi-vii.

22. Hurley C, McCarville MB, Shulkin BL, Mao S, Wu J, Navid F, Daw NC, Pappo AS, Bishop MW. Comparison of (18) F-FDG-PET-CT and Bone Scintigraphy for Evaluation of Osseous Metastases in Newly Diagnosed and Recurrent Osteosarcoma. Pediatr Blood Cancer. 2016; 63:1381-6.

23. Meyer JS, Nadel HR, Marina N, Womer RB, Brown KL, Eary JF, Gorlick R, Grier HE, Randall RL, Lawlor ER, Lessnick SL, Schomberg PJ, Kailo MD. Imaging guidelines for children with Ewing sarcoma and osteosarcoma: a report from the Children's Oncology Group Bone Tumor Committee. Pediatr Blood Cancer. 2008; 51:163-70.

24. Taupin T, Decouvelaere AV, Vaz G, Thiesse P. Accuracy of core needle biopsy for the diagnosis of osteosarcoma: A retrospective analysis of 73 patients. Diagn Interv Imaging. 2016; 97:327-31.

25. van Geel AN, Pastorino U, Jauch KW, Judson IR, van Coevorden F, Buesa JM, Nielsen OS, Boudinet A, Tursz T, Schmitz PI. Surgical treatment of lung metastases: The European Organization for Research and Treatment of Cancer-Soft Tissue and Bone Sarcoma Group study of 255 patients. Cancer. 1996; 77:675-82.

26. Bielack SS, Kempf-Bielack B, Delling G, Exner GU, Flege S, Helmke K, Kotz R, Salzer-Kuntschik M, Werner M, Winkelmann W, Zoubek A, Jurgens H, Winkler K. Prognostic factors in high-grade osteosarcoma of the extremities or trunk: an analysis of 1,702 patients treated on neoadjuvant cooperative osteosarcoma study group protocols. J Clin Oncol. 2002; 20:776-90.

27. Wittig JC, Bickels J, Priebat D, Jelinek J, Kellar-Graney K, Shmookler B, Malawer MM. Osteosarcoma: a multidisciplinary approach to diagnosis and treatment. Am Fam Physician. 2002; 65:1123-32.

28. Guma SR, Lee DA, Yu L, Gordon N, Hughes D, Stewart J, Wang WL, Kleinerman ES. Natural killer cell therapy and aerosol interleukin-2 for the treatment of osteosarcoma lung metastasis. Pediatr Blood Cancer. 2014; 61:618-26.

29. Schwinger W, Klass V, Benesch M, Lackner H, Dornbusch HJ, Sovinz P, Moser A, Schwantzer G, Urban C. Feasibility of high-dose interleukin-2 in heavily pretreated pediatric cancer patients. Ann Oncol. 2005; 16:1199-206.

30. D'Angelo SP, Tap WD, Schwartz GK, Carvajal RD. Corrigendum to "Sarcoma Immunotherapy: Past 
Approaches and Future Directions". Sarcoma. 2015; 2015:259817.

31. Wan J, Zhang X, Liu T, Zhang X. Strategies and developments of immunotherapies in osteosarcoma. Oncol Lett. 2016; 11:511-20.

32. Zumarraga JP, Baptista AM, Rosa LP, Caiero MT, Camargo OP. Serum Values of Alkaline Phosphatase and Lactate Dehydrogenase in Osteosarcoma. Acta Ortop Bras. 2016; 24:142-6.

33. Hu T, Yang Q, Xu J, Zhang Z, He N, Du Y. Role of betaisomerized C-terminal telopeptides (beta-CTx) and total procollagen type 1 amino-terminal propeptide (tP1NP) as osteosarcoma biomarkers. Int J Clin Exp Med. 2015; 8:890-6.

34. Pantel K, Alix-Panabieres C. Real-time liquid biopsy in cancer patients: fact or fiction? Cancer Res. 2013; 73:6384 8. https://doi.org/10.1158/0008-5472.CAN-13-2030.

35. Hofman P, Popper HH. Pathologists and liquid biopsies: to be or not to be? Virchows Arch. 2016; 469:601-9.

36. Raimondi L, De Luca A, Morelli E, Giavaresi G, Tagliaferri P, Tassone P, Amodio N. MicroRNAs: Novel Crossroads between Myeloma Cells and the Bone Marrow Microenvironment. Biomed Res Int. 2016; 2016:6504593.

37. Rossi M, Amodio N, Di Martino MT, Tagliaferri P, Tassone P, Cho WC. MicroRNA and multiple myeloma: from laboratory findings to translational therapeutic approaches. Curr Pharm Biotechnol. 2014; 15:459-67.

38. Denli AM, Tops BB, Plasterk RH, Ketting RF, Hannon GJ. Processing of primary microRNAs by the Microprocessor complex. Nature. 2004; 432:231-5.

39. Eulalio A, Huntzinger E, Nishihara T, Rehwinkel J, Fauser $\mathrm{M}$, Izaurralde E. Deadenylation is a widespread effect of miRNA regulation. RNA. 2009; 15:21-32.

40. Di Martino MT, Amodio N, Tassone P, Tagliaferri P. Functional Analysis of microRNA in Multiple Myeloma. Methods Mol Biol. 2016; 1375:181-94.

41. Kong YW, Ferland-McCollough D, Jackson TJ, Bushell M. microRNAs in cancer management. Lancet Oncol. 2012; 13:e249-58.

42. Rossi M, Amodio N, Di Martino MT, Caracciolo D, Tagliaferri P, Tassone P. From target therapy to miRNA therapeutics of human multiple myeloma: theoretical and technological issues in the evolving scenario. Curr Drug Targets. 2013; 14:1144-9.

43. Jones KB, Salah Z, Del Mare S, Galasso M, Gaudio E, Nuovo GJ, Lovat F, LeBlanc K, Palatini J, Randall RL, Volinia S, Stein GS, Croce CM, et al. miRNA signatures associate with pathogenesis and progression of osteosarcoma. Cancer Res. 2012; 72:1865-77.

44. Kobayashi E, Hornicek FJ, Duan Z. MicroRNA Involvement in Osteosarcoma. Sarcoma. 2012; 2012:359739.

45. Sarver AL, Phalak R, Thayanithy V, Subramanian S. S-MED: sarcoma microRNA expression database. Lab Invest. 2010; 90:753-61.

46. Hardikar AA, Farr RJ, Joglekar MV. Circulating microRNAs: understanding the limits for quantitative measurement by real-time PCR. J Am Heart Assoc. 2014; 3:e000792.

47. Valencia K, Martin-Fernandez M, Zandueta C, Ormazabal C, Martinez-Canarias S, Bandres E, de la Piedra C, Lecanda F. miR-326 associates with biochemical markers of bone turnover in lung cancer bone metastasis. Bone. 2013; 52:532-9.

48. Liang Z, Wu H, Xia J, Li Y, Zhang Y, Huang K, Wagar N, Yoon Y, Cho HT, Scala S, Shim H. Involvement of miR326 in chemotherapy resistance of breast cancer through modulating expression of multidrug resistance-associated protein 1. Biochem Pharmacol. 2010; 79:817-24.

49. Cao L, Wang J, Wang PQ. MiR-326 is a diagnostic biomarker and regulates cell survival and apoptosis by targeting Bcl-2 in osteosarcoma. Biomed Pharmacother. 2016; 84:828-35.

50. Zhao H, Li M, Li L, Yang X, Lan G, Zhang Y. MiR-133b is down-regulated in human osteosarcoma and inhibits osteosarcoma cells proliferation, migration and invasion, and promotes apoptosis. PLoS One. 2013; 8:e83571.

51. Bao YP, Yi Y, Peng LL, Fang J, Liu KB, Li WZ, Luo HS. Roles of microRNA-206 in osteosarcoma pathogenesis and progression. Asian Pac J Cancer Prev. 2013; 14:3751-5.

52. Zhang C, Yao C, Li H, Wang G, He X. Serum levels of microRNA-133b and microRNA-206 expression predict prognosis in patients with osteosarcoma. Int J Clin Exp Pathol. 2014; 7:4194-203.

53. Wang NG, Wang DC, Tan BY, Wang F, Yuan ZN. Downregulation of microRNA152 is associated with the diagnosis and prognosis of patients with osteosarcoma. Int J Clin Exp Pathol. 2015; 8:9314-9.

54. Niu J, Sun Y, Guo Q, Niu D, Liu B. Serum miR-95-3p is a diagnostic and prognostic marker for osteosarcoma. Springerplus. 2016; 5:1947.

55. Tian Q, Jia J, Ling S, Liu Y, Yang S, Shao Z. A causal role for circulating miR-34b in osteosarcoma. Eur J Surg Oncol. 2014; 40:67-72.

56. Cai H, Zhao H, Tang J, Wu H. Serum miR-195 is a diagnostic and prognostic marker for osteosarcoma. J Surg Res. 2015; 194:505-10.

57. Dong J, Liu Y, Liao W, Liu R, Shi P, Wang L. miRNA-223 is a potential diagnostic and prognostic marker for osteosarcoma. J Bone Oncol. 2016; 5:74-9.

58. Pang PC, Shi XY, Huang WL, Sun K. miR-497 as a potential serum biomarker for the diagnosis and prognosis of osteosarcoma. Eur Rev Med Pharmacol Sci. 2016; 20:3765-9.

59. Gougelet A, Pissaloux D, Besse A, Perez J, Duc A, Dutour A, Blay JY, Alberti L. Micro-RNA profiles in osteosarcoma as a predictive tool for ifosfamide response. Int $\mathrm{J}$ Cancer. 2011; 129:680-90.

60. Wang F, Yu D, Liu Z, Wang R, Xu Y, Cui H, Zhao T. MiR125b Functions as a Tumor Suppressor and Enhances Chemosensitivity to Cisplatin in Osteosarcoma. Technol Cancer Res Treat. 2016; 15:NP105-NP12. 
61. Luo Z, Liu M, Zhang H, Xia Y. Association of circulating miR-125b and survival in patients with osteosarcoma-A single center experience. J Bone Oncol. 2016; 5:167-72.

62. Wang X, Ning Y, Yang L, Liu H, Wu C, Wang S, Guo $X$. Diagnostic value of circulating microRNAs for osteosarcoma in Asian populations: a meta-analysis. Clin Exp Med. 2017; 17:175-83.

63. Larrea E, Sole C, Manterola L, Goicoechea I, Armesto M, Arestin M, Caffarel MM, Araujo AM, Araiz M, FernandezMercado M, Lawrie CH. New Concepts in Cancer Biomarkers: Circulating miRNAs in Liquid Biopsies. Int J Mol Sci. 2016; 17.

64. Ouyang L, Liu P, Yang S, Ye S, Xu W, Liu X. A threeplasma miRNA signature serves as novel biomarkers for osteosarcoma. Med Oncol. 2013; 30:340.

65. Zhang C, Yao C, Li H, Wang G, He X. Combined elevation of microRNA-196a and microRNA-196b in sera predicts unfavorable prognosis in patients with osteosarcomas. Int J Mol Sci. 2014; 15:6544-55.

66. Lian F, Cui Y, Zhou C, Gao K, Wu L. Identification of a plasma four-microRNA panel as potential noninvasive biomarker for osteosarcoma. PLoS One. 2015; 10:e0121499.

67. Zhou G, Lu M, Chen J, Li C, Zhang J, Chen J, Shi X, Wu $\mathrm{S}$. Identification of miR-199a-5p in serum as noninvasive biomarkers for detecting and monitoring osteosarcoma. Tumour Biol. 2015; 36:8845-52.

68. Xue Z, Zhao J, Niu L, An G, Guo Y, Ni L. Up-Regulation of MiR-300 Promotes Proliferation and Invasion of Osteosarcoma by Targeting BRD7. PLoS One. 2015; 10:e0127682.

69. Liu JD, Xin Q, Tao CS, Sun PF, Xu P, Wu B, Qu L, Li SZ. Serum miR-300 as a diagnostic and prognostic biomarker in osteosarcoma. Oncol Lett. 2016; 12:3912-8.

70. Yu J, Xie F, Bao X, Chen W, Xu Q. miR-300 inhibits epithelial to mesenchymal transition and metastasis by targeting Twist in human epithelial cancer. Mol Cancer. 2014; 13:121.

71. Zhang D, Yang G, Chen X, Li C, Wang L, Liu Y, Han D, Liu H, Hou X, Zhang W, Li C, Han Z, Gao X, et al. mir300 promotes self-renewal and inhibits the differentiation of glioma stem-like cells. J Mol Neurosci. 2014; 53:637-44.

72. Amodio N, Rossi M, Raimondi L, Pitari MR, Botta C, Tagliaferri P, Tassone P. miR-29s: a family of epi-miRNAs with therapeutic implications in hematologic malignancies. Oncotarget. 2015; 6:12837-61. https://doi.org/10.18632/ oncotarget.3805.

73. Yan B, Guo Q, Fu FJ, Wang Z, Yin Z, Wei YB, Yang JR. The role of miR-29b in cancer: regulation, function, and signaling. Onco Targets Ther. 2015; 8:539-48. https://doi. org/10.2147/OTT.S75899.

74. Li Z, Hassan MQ, Jafferji M, Aqeilan RI, Garzon R, Croce CM, van Wijnen AJ, Stein JL, Stein GS, Lian JB. Biological functions of miR-29b contribute to positive regulation of osteoblast differentiation. J Biol Chem. 2009; 284:15676-84.
75. Kapinas K, Kessler CB, Delany AM. miR-29 suppression of osteonectin in osteoblasts: regulation during differentiation and by canonical Wnt signaling. J Cell Biochem. 2009; 108:216-24.

76. Rossi M, Pitari MR, Amodio N, Di Martino MT, Conforti F, Leone E, Botta C, Paolino FM, Del Giudice T, Iuliano E, Caraglia M, Ferrarini M, Giordano A, et al. miR-29b negatively regulates human osteoclastic cell differentiation and function: implications for the treatment of multiple myeloma-related bone disease. J Cell Physiol. 2013; 228:1506-15.

77. Namlos HM, Meza-Zepeda LA, Baroy T, Ostensen IH, Kresse SH, Kuijjer ML, Serra M, Burger H, Cleton-Jansen AM, Myklebost O. Modulation of the osteosarcoma expression phenotype by microRNAs. PLoS One. 2012; 7:e48086.

78. Di Fiore R, Fanale D, Drago-Ferrante R, Chiaradonna F, Giuliano M, De Blasio A, Amodeo V, Corsini LR, Bazan V, Tesoriere G, Vento R, Russo A. Genetic and molecular characterization of the human osteosarcoma $3 \mathrm{AB}-\mathrm{OS}$ cancer stem cell line: a possible model for studying osteosarcoma origin and stemness. J Cell Physiol. 2013; 228:1189-201.

79. Hong Q, Fang J, Pang Y, Zheng J. Prognostic value of the microRNA-29 family in patients with primary osteosarcomas. Med Oncol. 2014; 31:37.

80. Fujiwara T, Uotani K, Yoshida A, Morita T, Nezu Y, Kobayashi E, Yoshida A, Uehara T, Omori T, Sugiu K, Komatsubara T, Takeda K, Kunisada T, et al. Clinical significance of circulating miR-25-3p as a novel diagnostic and prognostic biomarker in osteosarcoma. Oncotarget. 2017; 8:33375-92. https://doi.org/10.18632/oncotarget.16498.

81. Gao Y, Luo LH, Li S, Yang C. miR-17 inhibitor suppressed osteosarcoma tumor growth and metastasis via increasing PTEN expression. Biochem Biophys Res Commun. 2014; 444:230-4.

82. Li S, Gao Y, Wang Y, Wang K, Dai ZP, Xu D, Liu W, Li ZL, Zhang ZD, Yang SH, Yang C. Serum microRNA-17 functions as a prognostic biomarker in osteosarcoma. Oncol Lett. 2016; 12:4905-10.

83. Gulla A, Di Martino MT, Gallo Cantafio ME, Morelli E, Amodio N, Botta C, Pitari MR, Lio SG, Britti D, Stamato MA, Hideshima T, Munshi NC, Anderson KC, et al. A 13 mer LNA-i-miR-221 Inhibitor Restores Drug Sensitivity in Melphalan-Refractory Multiple Myeloma Cells. Clin Cancer Res. 2016; 22:1222-33.

84. Di Martino MT, Gulla A, Gallo Cantafio ME, Altomare E, Amodio N, Leone E, Morelli E, Lio SG, Caracciolo D, Rossi M, Frandsen NM, Tagliaferri P, Tassone P. In vitro and in vivo activity of a novel locked nucleic acid (LNA)inhibitor-miR-221 against multiple myeloma cells. PLoS One. 2014; 9:e89659.

85. Zhao G, Cai C, Yang T, Qiu X, Liao B, Li W, Ji Z, Zhao J, Zhao H, Guo M, Ma Q, Xiao C, Fan Q, et al. MicroRNA-221 induces cell survival and cisplatin resistance through PI3K/Akt pathway in human osteosarcoma. PLoS One. 2013; 8:e53906. 
86. Yang Z, Zhang Y, Zhang X, Zhang M, Liu H, Zhang S, Qi B, Sun X. Serum microRNA-221 functions as a potential diagnostic and prognostic marker for patients with osteosarcoma. Biomed Pharmacother. 2015; 75:153-8.

87. Guttilla IK, White BA. Coordinate regulation of FOXO1 by miR-27a, miR-96, and miR-182 in breast cancer cells. J Biol Chem. 2009; 284:23204-16.

88. Mertens-Talcott SU, Chintharlapalli S, Li X, Safe S. The oncogenic microRNA-27a targets genes that regulate specificity protein transcription factors and the G2-M checkpoint in MDA-MB-231 breast cancer cells. Cancer Res. 2007; 67:11001-11.

89. Chintharlapalli S, Papineni S, Abdelrahim M, Abudayyeh A, Jutooru I, Chadalapaka G, Wu F, Mertens-Talcott S, Vanderlaag K, Cho SD, Smith R 3rd, Safe S. Oncogenic microRNA-27a is a target for anticancer agent methyl 2-cyano-3,11-dioxo-18beta-olean-1,12-dien-30-oate in colon cancer cells. Int J Cancer. 2009; 125:1965-74.

90. Pan W, Wang H, Jianwei R, Ye Z. MicroRNA-27a promotes proliferation, migration and invasion by targeting MAP2K4 in human osteosarcoma cells. Cell Physiol Biochem. 2014; 33:402-12.

91. Tang J, Zhao H, Cai H, Wu H. Diagnostic and prognostic potentials of microRNA-27a in osteosarcoma. Biomed Pharmacother. 2015; 71:222-6. https://doi.org/10.1016/j. biopha.2015.01.025.

92. Sun Y, He N, Dong Y, Jiang C. MiR-24-BIM-Smac/ DIABLO axis controls the sensitivity to doxorubicin treatment in osteosarcoma. Sci Rep. 2016; 6:34238.

93. El-Khoury V, Pierson S, Kaoma T, Bernardin F, Berchem G. Assessing cellular and circulating miRNA recovery: the impact of the RNA isolation method and the quantity of input material. Sci Rep. 2016; 6:19529.

94. Huang RS, Gamazon ER, Ziliak D, Wen Y, Im HK, Zhang W, Wing C, Duan S, Bleibel WK, Cox NJ, Dolan ME. Population differences in microRNA expression and biological implications. RNA Biol. 2011; 8:692-701.

95. Duttagupta R, Jiang R, Gollub J, Getts RC, Jones KW. Impact of cellular miRNAs on circulting miRNA biomarker signatures. PLoS One. 2011; 6:e20769.

96. Wang YT, Tsai PC, Liao YC, Hsu CY, Juo SH. Circulating microRNAs have a sex-specific association with metabolic syndrome. J Biomed Sci. 2013; 20:72.

97. de Boer HC, van Solingen C, Prins J, Duijs JM, Huisman MV, Rabelink TJ, van Zonneveld AJ. Aspirin treatment hampers the use of plasma microRNA-126 as a biomarker for the progression of vascular disease. Eur Heart J. 2013; 34:3451-7.

98. Badrnya S, Baumgartner R, Assinger A. Smoking alters circulating plasma microvesicle pattern and microRNA signatures. Thromb Haemost. 2014; 112:128-36.

99. Witwer KW. XenomiRs and miRNA homeostasis in health and disease: evidence that diet and dietary miRNAs directly and indirectly influence circulating miRNA profiles. RNA Biol. 2012; 9:1147-54.
100. Kung JT, Colognori D, Lee JT. Long noncoding RNAs: past, present, and future. Genetics. 2013; 193:651-69.

101. Xue WJ, Ying XL, Jiang JH, Xu YH. Prostate cancer antigen 3 as a biomarker in the urine for prostate cancer diagnosis: a meta-analysis. J Cancer Res Ther. 2014; 10:C218-21.

102. Zhou X, Yin C, Dang Y, Ye F, Zhang G. Identification of the long non-coding RNA H19 in plasma as a novel biomarker for diagnosis of gastric cancer. Sci Rep. 2015; 5:11516.

103. Xie H, Ma H, Zhou D. Plasma HULC as a promising novel biomarker for the detection of hepatocellular carcinoma. Biomed Res Int. 2013; 2013:136106.

104. Ji P, Diederichs S, Wang W, Boing S, Metzger R, Schneider PM, Tidow N, Brandt B, Buerger H, Bulk E, Thomas M, Berdel WE, Serve H, et al. MALAT-1, a novel noncoding RNA, and thymosin beta4 predict metastasis and survival in early-stage non-small cell lung cancer. Oncogene. 2003; 22:8031-41.

105. Qi P, Du X. The long non-coding RNAs, a new cancer diagnostic and therapeutic gold mine. Mod Pathol. 2013; 26:155-65.

106. Zhu KP, Zhang CL, Shen GQ, Zhu ZS. Long noncoding RNA expression profiles of the doxorubicin-resistant human osteosarcoma cell line MG63/DXR and its parental cell line MG63 as ascertained by microarray analysis. Int J Clin Exp Pathol. 2015; 8:8754-73.

107. Li JP, Liu LH, Li J, Chen Y, Jiang XW, Ouyang YR, Liu YQ, Zhong H, Li H, Xiao T. Microarray expression profile of long noncoding RNAs in human osteosarcoma. Biochem Biophys Res Commun. 2013; 433:200-6.

108. Ma B, Li M, Zhang L, Huang M, Lei JB, Fu GH, Liu CX, Lai QW, Chen QQ, Wang YL. Upregulation of long non-coding RNA TUG1 correlates with poor prognosis and disease status in osteosarcoma. Tumour Biol. 2016; 37:4445-55.

109. Xia WK, Lin QF, Shen D, Liu ZL, Su J, Mao WD. Clinical implication of long noncoding RNA 91H expression profile in osteosarcoma patients. Onco Targets Ther. 2016; 9:4645-52.

110. Shang C, Guo Y, Zhang J, Huang B. Silence of long noncoding RNA UCA1 inhibits malignant proliferation and chemotherapy resistance to adriamycin in gastric cancer. Cancer Chemother Pharmacol. 2016; 77:1061-7.

111. Zhang L, Cao X, Zhang L, Zhang X, Sheng H, Tao K. UCA1 overexpression predicts clinical outcome of patients with ovarian cancer receiving adjuvant chemotherapy. Cancer Chemother Pharmacol. 2016; 77:629-34.

112. Wen JJ, Ma YD, Yang GS, Wang GM. Analysis of circulating long non-coding RNA UCA1 as potential biomarkers for diagnosis and prognosis of osteosarcoma. Eur Rev Med Pharmacol Sci. 2017; 21:498-503.

113. Han F, Wang C, Wang Y, Zhang L. Long noncoding RNA ATB promotes osteosarcoma cell proliferation, migration and invasion by suppressing miR-200s. Am J Cancer Res. 2017; 7:770-83. 114. Dong Y, Liang G, Yuan B, Yang C, Gao R, Zhou X. MALAT1 promotes the proliferation and 
metastasis of osteosarcoma cells by activating the PI3K/Akt pathway. Tumour Biol. 2015; 36:1477-86.

115. Gao KT, Lian D. Long non-coding RNA MALAT1 is an independent prognostic factor of osteosarcoma. Eur Rev Med Pharmacol Sci. 2016; 20:3561-5.

116. Huo Y, Li Q, Wang X, Jiao X, Zheng J, Li Z, Pan X. MALAT1 predicts poor survival in osteosarcoma patients and promotes cell metastasis through associating with EZH2. Oncotarget. 2017; 8:46933-47006. https://doi. org/10.18632.oncotarget.16551.

117. Joosse SA, Pantel K. Biologic challenges in the detection of circulating tumor cells. Cancer Res. 2013; 73:8-11.

118. Plaks V, Koopman CD, Werb Z. Cancer. Circulating tumor cells. Science. 2013; 341:1186-8.

119. Alix-Panabieres C, Schwarzenbach H, Pantel K. Circulating tumor cells and circulating tumor DNA. Annu Rev Med. 2012; 63:199-215.

120. Chinen LT, Mello CA, Abdallah EA, Ocea LM, Buim ME, Breve NM, Gasparini JLJ, Fanelli MF, PaterliniBrechot P. Isolation, detection, and immunomorphological characterization of circulating tumor cells (CTCs) from patients with different types of sarcoma using isolation by size of tumor cells: a window on sarcoma-cell invasion. Onco Targets Ther. 2014; 7:1609-17.

121. Zhu QS, Rosenblatt K, Huang KL, Lahat G, Brobey R, Bolshakov S, Nguyen T, Ding Z, Belousov R, Bill K, Luo X, Lazar A, Dicker A, et al. Vimentin is a novel AKT1 target mediating motility and invasion. Oncogene. 2011; 30:457-70.

122. Satelli A, Li S. Vimentin in cancer and its potential as a molecular target for cancer therapy. Cell Mol Life Sci. 2011; 68:3033-46.

123. Wong IH, Chan AT, Johnson PJ. Quantitative analysis of circulating tumor cells in peripheral blood of osteosarcoma patients using osteoblast-specific messenger RNA markers: a pilot study. Clin Cancer Res. 2000; 6:2183-8.

124. Hatano H, Kawashima H, Ogose A, Hotta T, Endo N. A PCR-ELISA assay for the detection of disseminated osteosarcoma cells in a mouse metastatic model. J Orthop Sci. 2001; 6:269-75. 125. Khanna C, Wan X, Bose S, Cassaday R, Olomu O, Mendoza A, Yeung C, Gorlick R, Hewitt SM, Helman LJ. The membrane-cytoskeleton linker ezrin is necessary for osteosarcoma metastasis. Nat Med. 2004; 10:182-6.

126. Wang YF, Shen JN, Xie XB, Wang J, Huang G. Expression change of ezrin as a prognostic factor in primary osteosarcoma. Med Oncol. 2011; 28:S636-43.

127. Salas S, Bartoli C, Deville JL, Gaudart J, Fina F, Calisti A, Bollini G, Curvale G, Gentet JC, Duffaud F, FigarellaBranger D, Bouvier C. Ezrin and alpha-smooth muscle actin are immunohistochemical prognostic markers in conventional osteosarcomas. Virchows Arch. 2007; 451:999-1007.

128. Zhong GX, Feng SD, Shen R, Wu ZY, Chen F, Zhu X. The clinical significance of the Ezrin gene and circulating tumor cells in osteosarcoma. Onco Targets Ther. 2017; 10:527-33.
129. Zhang H, Gao P, Xiao X, Heger M, Geng L, Fan B, Yuan Y, Huang C, Chen G, Liu Y, Hu Y, Yu X, Wu S, et al. A liquid biopsy-based method for the detection and quantification of circulating tumor cells in surgical osteosarcoma patients. Int J Oncol. 2017.

130. Snyder MW, Kircher M, Hill AJ, Daza RM, Shendure J. Cell-free DNA Comprises an In Vivo Nucleosome Footprint that Informs Its Tissues-Of-Origin. Cell. 2016; 164:57-68.

131. Diaz LA Jr, Bardelli A. Liquid biopsies: genotyping circulating tumor DNA. J Clin Oncol. 2014; 32:579-86.

132. Bettegowda C, Sausen M, Leary RJ, Kinde I, Wang Y, Agrawal N, Bartlett BR, Wang H, Luber B, Alani RM, Antonarakis ES, Azad NS, Bardelli A, et al. Detection of circulating tumor DNA in early- and late-stage human malignancies. Sci Transl Med. 2014; 6:224ra24.

133. Yong E. Cancer biomarkers: Written in blood. Nature. 2014; 511:524-6.

134. De Mattos-Arruda L, Weigelt B, Cortes J, Won HH, Ng CK, Nuciforo P, Bidard FC, Aura C, Saura C, Peg V, Piscuoglio $\mathrm{S}$, Oliveira M, Smolders Y, et al. Capturing intra-tumor genetic heterogeneity by de novo mutation profiling of circulating cell-free tumor DNA: a proof-of-principle. Ann Oncol. 2014; 25:1729-35.

135. Fenizia F, De Luca A, Pasquale R, Sacco A, Forgione L, Lambiase M, Iannaccone A, Chicchinelli N, Franco R, Rossi A, Morabito A, Rocco G, Piccirillo MC, et al. EGFR mutations in lung cancer: from tissue testing to liquid biopsy. Future Oncol. 2015; 11:1611-23.

136. Kovac M, Blattmann C, Ribi S, Smida J, Mueller NS, Engert F, Castro-Giner F, Weischenfeldt J, Kovacova M, Krieg A, Andreou D, Tunn PU, Durr HR, et al. Exome sequencing of osteosarcoma reveals mutation signatures reminiscent of BRCA deficiency. Nat Commun. 2015; 6:8940.

137. Kanwal R, Gupta S. Epigenetic modifications in cancer. Clin Genet. 2012; 81:303-11.

138. Ignatiadis M, Dawson SJ. Circulating tumor cells and circulating tumor DNA for precision medicine: dream or reality? Ann Oncol. 2014; 25:2304-13.

139. Al-Romaih K, Somers GR, Bayani J, Hughes S, Prasad M, Cutz JC, Xue H, Zielenska M, Wang Y, Squire JA. Modulation by decitabine of gene expression and growth of osteosarcoma U2OS cells in vitro and in xenografts: identification of apoptotic genes as targets for demethylation. Cancer Cell Int. 2007; 7:14.

140. Lu J, Song G, Tang Q, Zou C, Han F, Zhao Z, Yong B, Yin J, Xu H, Xie X, Kang T, Lam Y, Yang H, et al. IRX1 hypomethylation promotes osteosarcoma metastasis via induction of CXCL14/NF-kappaB signaling. J Clin Invest. $2015 ; 125: 1839-56$.

141. Corrado C, Raimondo S, Chiesi A, Ciccia F, De Leo G, Alessandro R. Exosomes as intercellular signaling organelles involved in health and disease: basic science and clinical applications. Int J Mol Sci. 2013; 14:5338-66.

142. Raimondi L, De Luca A, Amodio N, Manno M, Raccosta S, Taverna S, Bellavia D, Naselli F, Fontana S, Schillaci O, 
Giardino R, Fini M, Tassone $\mathrm{P}$, et al. Involvement of multiple myeloma cell-derived exosomes in osteoclast differentiation. Oncotarget. 2015; 6:13772-89. https://doi. org/10.18632/oncotarget.3830.

143. Logozzi M, De Milito A, Lugini L, Borghi M, Calabro L, Spada M, Perdicchio M, Marino ML, Federici C, Iessi E, Brambilla D, Venturi G, Lozupone F, et al. High levels of exosomes expressing CD63 and caveolin-1 in plasma of melanoma patients. PLoS One. 2009; 4:e5219.

144. O'Brien K, Rani S, Corcoran C, Wallace R, Hughes L, Friel AM, McDonnell S, Crown J, Radomski MW, O’Driscoll L. Exosomes from triple-negative breast cancer cells can transfer phenotypic traits representing their cells of origin to secondary cells. Eur J Cancer. 2013; 49:1845-59.

145. Kahlert C, Kalluri R. Exosomes in tumor microenvironment influence cancer progression and metastasis. J Mol Med (Berl). 2013; 91:431-7.

146. Whiteside TL. Tumor-Derived Exosomes and Their Role in Cancer Progression. Adv Clin Chem. 2016; 74:103-41.

147. An T, Qin S, Xu Y, Tang Y, Huang Y, Situ B, Inal JM, Zheng L. Exosomes serve as tumour markers for personalized diagnostics owing to their important role in cancer metastasis. J Extracell Vesicles. 2015; 4:27522.

148. Taylor DD, Shah S. Methods of isolating extracellular vesicles impact down-stream analyses of their cargoes. Methods. 2015; 87:3-10.

149. Ziaei P, Geruntho JJ, Marin-Flores OG, Berkman CE, Norton MG. Silica nanostructured platform for affinity capture of tumor-derived exosomes. Journal of Materials Science. 2017; 52:6907-16.

150. Alegre E, Zubiri L, Perez-Gracia JL, Gonzalez-Cao M, Soria L, Martin-Algarra S, Gonzalez A. Circulating melanoma exosomes as diagnostic and prognosis biomarkers. Clin Chim Acta. 2016; 454:28-32.

151. Melo SA, Luecke LB, Kahlert C, Fernandez AF, Gammon ST, Kaye J, LeBleu VS, Mittendorf EA, Weitz J, Rahbari N, Reissfelder C, Pilarsky C, Fraga MF, et al. Glypican-1 identifies cancer exosomes and detects early pancreatic cancer. Nature. 2015; 523:177-82.

152. Liu Q, Yu Z, Yuan S, Xie W, Li C, Hu Z, Xiang Y, Wu N, Wu L, Bai L, Li Y. Circulating exosomal microRNAs as prognostic biomarkers for non-small-cell lung cancer. Oncotarget. 2017; 8:13048-58. https://doi.org/10.18632/ oncotarget. 14369.

153. Jerez S, Araya H, Thaler R, Charlesworth MC, Lopez-Solis R, Kalergis AM, Cespedes PF, Dudakovic A, Stein GS, van Wijnen AJ, Galindo M. Proteomic Analysis of Exosomes and Exosome-Free Conditioned Media From Human Osteosarcoma Cell Lines Reveals Secretion of Proteins Related to Tumor Progression. J Cell Biochem. 2017; 118:351-60.

154. Baglio SR, Lagerweij T, Perez-Lanzon M, Ho XD, Leveille N, Melo SA, Cleton-Jansen AM, Jordanova ES, Roncuzzi L, Greco M, van Eijndhoven MAJ, Grisendi G, Dominici
M, et al. Blocking Tumor-Educated MSC Paracrine Activity Halts Osteosarcoma Progression. Clin Cancer Res. 2017.

155. Torreggiani E, Roncuzzi L, Perut F, Zini N, Baldini N. Multimodal transfer of MDR by exosomes in human osteosarcoma. Int J Oncol. 2016; 49:189-96.

156. Xu JF, Wang YP, Zhang SJ, Chen Y, Gu HF, Dou XF, Xia B, Bi Q, Fan SW. Exosomes containing differential expression of microRNA and mRNA in osteosarcoma that can predict response to chemotherapy. Oncotarget. 2017; 8:7596875978. https://doi.org/10.18632/oncotarget.18373.

157. Diamandis EP. The failure of protein cancer biomarkers to reach the clinic: why, and what can be done to address the problem? BMC Med. 2012; 10:87.

158. Drucker E, Krapfenbauer K. Pitfalls and limitations in translation from biomarker discovery to clinical utility in predictive and personalised medicine. EPMA J. 2013; 4:7.

159. Li FP, Fraumeni JF Jr. Soft-tissue sarcomas, breast cancer, and other neoplasms. A familial syndrome? Ann Intern Med. 1969; 71:747-52.

160. Malkin D, Li FP, Strong LC, Fraumeni JF Jr, Nelson CE, Kim DH, Kassel J, Gryka MA, Bischoff FZ, Tainsky MA. Germ line p53 mutations in a familial syndrome of breast cancer, sarcomas, and other neoplasms. Science. 1990; 250:1233-8.

161. Olivier M, Goldgar DE, Sodha N, Ohgaki H, Kleihues P, Hainaut P, Eeles RA. Li-Fraumeni and related syndromes: correlation between tumor type, family structure, and TP53 genotype. Cancer Res. 2003; 63:6643-50.

162. Wadayama B, Toguchida J, Shimizu T, Ishizaki K, Sasaki MS, Kotoura Y, Yamamuro T. Mutation spectrum of the retinoblastoma gene in osteosarcomas. Cancer Res. 1994; 54:3042-8.

163. Hicks MJ, Roth JR, Kozinetz CA, Wang LL. Clinicopathologic features of osteosarcoma in patients with Rothmund-Thomson syndrome. J Clin Oncol. 2007; 25:370-5.

164. Lindor NM, Furuichi Y, Kitao S, Shimamoto A, Arndt C, Jalal S. Rothmund-Thomson syndrome due to RECQ4 helicase mutations: report and clinical and molecular comparisons with Bloom syndrome and Werner syndrome. Am J Med Genet. 2000; 90:223-8.

165. Sanz MM, German J, Cunniff C. (1993). Bloom's Syndrome. In: Pagon RA, Adam MP, Ardinger HH, Wallace SE, Amemiya A, Bean LJH, Bird TD, Ledbetter N, Mefford HC, Smith RJH and Stephens K, eds. GeneReviews(R). (Seattle (WA).

166. Lee RS, Higgs D, Haddo O, Pringle J, Briggs TW. Osteosarcoma associated with diamond-blackfan anaemia: a case of a child receiving growth hormone therapy. Sarcoma. 2004; 8:47-9.

167. Hansen MF, Seton M, Merchant A. Osteosarcoma in Paget's disease of bone. J Bone Miner Res. 2006; 21:P58-63.

168. Kalra S, Grimer RJ, Spooner D, Carter SR, Tillman RM, Abudu A. Radiation-induced sarcomas of bone: factors that affect outcome. J Bone Joint Surg Br. 2007; 89:808-13. 
169. Le Vu B, de Vathaire F, Shamsaldin A, Hawkins MM, Grimaud E, Hardiman C, Diallo I, Vassal G, Bessa E, Campbell S, Panis X, Daly-Schveitzer N, Lagrange JL, et al. Radiation dose, chemotherapy and risk of osteosarcoma after solid tumours during childhood. Int J Cancer. 1998; 77:370-7.

170. Enneking WF, Spanier SS, Goodman MA. A system for the surgical staging of musculoskeletal sarcoma. Clin Orthop Relat Res. 1980:106-20.
171. Wang L, Gao H, Gong N, Gong M. Downregulation of microRNA-497 is associated with upregulation of synuclein gamma in patients with osteosarcoma. Exp Ther Med. 2016; $12: 3761-6$. 